\title{
İşverenin Engelli İşçi Çalıştırma Yükümlülüğü
}

\author{
Ayşe Köme Akpulat*
}

Öz

Engelliler; sağlık, eğitim ve istihdam konusunda çeşitli sorunlar yaşamakta ve bu anlamda dezavantajı gruplar arasında yer almaktadır. 1948 tarihli İnsan Hakları Evrensel Beyannamesi'nin 25. maddesinde, herkesin engellilikten doğan geçim sıkıntısı durumunda korunması gerektiği açıklanmıştır. Birleşmiş Milletler Engelli Kişilerin Haklarına iliş̧in Sözleşme'de de engellilerin hakları ve taraf devletlerin yükümlülükleri düzenlenmiştir. Bu Sözleşmenin 27. maddesine göre, taraf devletler çalışma hakkının gerçekleşmesini güvence altına alacak ve destekleyeceklerdir. Türkiye'de de engellilere ilişkin çok sayıda yasal düzenleme yapılmıştır. Bunlardan biri de 4857 sayııı iş Kanunu'nun 30. maddesidir. Maddede, işverenlere işyerlerinde engelli iş̧̧i çalıştırma yükümlülüğü getirilmiştir. Buna göre, elli veya daha fazla sayıda iş̧̧i çalıştran işverenler, belirli sayıdaki engelli iş̧̧iyi meslek, beden ve ruhi durumlarına uygun işlerde çalıştrmakla yükümlüdür. Bu sayı özel sektör işyerlerinde yüzde üç, kamu işyerlerinde ise yüzde dörttür. Aynı il sınırları içinde birden fazla işyeri bulunan işverenin bu kapsamda çalıştırmakla yükümlü olduğu işçi sayısı, toplam iş̧̧i sayısına göre hesaplanır. Bu çalışma, İş Kanunu'nun 30. maddesini ilgili mevzuat çerçevesinde incelemeyi amaçlamaktadır.

\section{Anahtar Kelimeler \\ İs Kanunu, Engelliler, İstihdam, Çalışma hakkı, Sosyal devlet, Korumalı işyeri}

\section{The Liability of the Employer to Employ Disabled Employee}

\begin{abstract}
Disabled people, having various problems with health, education, and employment, are among the disadvantaged groups. In Article 25 of the Universal Declaration of Human Rights 1948, it is explained that everyone should be protected in case of a lack of livelihood arising from disability. The United Nations Convention on the Rights of Persons with Disabilities also regulates the rights of persons with disabilities and the obligations of the contracting states. According to Article 27 of the Convention, contracting states shall secure and support, ensuring the right to work. Also, in Turkey, a large number of legal arrangements have been made for persons with disabilities. One of them is article 30 of Labour Law no. 4857. By this Article, employers are obliged to employ disabled workers in the workplace. Accordingly, employers employing fifty or more workers are obliged to employ a certain number of disabled workers in jobs suitable for their occupation, body and mental status. This number is 3 percent in private sector workplaces and 4 percent in public workplaces. The number of workers the employer is obliged to employ in this scope is calculated according to the total number of employees for those employers who have more than one workplace within the same province boundaries. This study aims to examine article 30 of the Labour Law within the framework of the relevant legislation.
\end{abstract}

\section{Keywords}

Labour Law, Person with disabilities, Employment, Right to work, Social state, Sheltered workplaces

\footnotetext{
* Sorumlu Yazar: Ayşe Köme Akpulat (Dr.), İstanbul Üniversitesi, Hukuk Fakültesi, İş ve Sosyal Güvenlik Hukuku Anabilim Dalı, İstanbul, Türkiye. E-posta: aysekome@istanbul.edu.tr ORCID: 0000-0002-5271-2961
}

Attf: Kome Akpulat A, “İşverenin Engelli İşçi Çalıştırma Yükümlülüğü” (2019) 77(2) İstanbul Hukuk Mecmuası 523.

https://doi.org/10.26650/mecmua.2019.77.2.0003 


\section{Extended Summary}

Involvement of persons with disabilities in business life is extremely important - just as much as in their access to education and health services - and in their enjoyment of social protection because unemployment makes individuals becoming unemployed feel like they are useless. Involvement of persons with disabilities in business life, and pursuing the same eliminates the social effects caused by the risk of unemployment. In addition, working persons with disabilities benefit from social insurance protection based on their work, and thus a decrease occurs in the expenses made for persons with disabilities from the social security budget. While the policies relevant to persons with disabilities started with passive policies such as protecting persons with disabilities, today they have transformed into active policies such as ensuring the complete participation of persons with disabilities in employment.

In Turkey, the number of persons with disabilities recorded on the National Database on Persons with Disabilities is 2.461.828 for the first half of the year 2019 . And the rate of participation of persons with disabilities in employment is 22.1 percent. When compared with the data for the EU and OECD, this number is very low. Thus, increasing the participation in employment of persons with disabilities is also among the objectives relevant to business life.

When the legal regulations in Turkey are examined, it can be observed that rules relevant to the protection of persons with disabilities have taken place in Constitutional Law for the first time. According to Article 17 of Constitutional Law, everyone has the right to live, and to preserve and improve their material and moral presence. And, according to Article 49 of Constitutional Law, working is everyone's right and obligation. The government takes the required measures to increase the standard of living of employees, protect the unemployed, and support working. The government's actualization of this obligation is especially important in terms of persons with disabilities who are experiencing many difficulties in involvement in business life. For this reason, it is required that the government should take special measures for persons with disabilities, and to provide the work environment for them. Hence, in Article 50 of Constitutional Law, it has been emphasized that no one could be employed in works not conforming to their strength, and the rule of "the ones having physical and psychological insufficiency are distinctively protected in terms of working conditions" has been established.

And the most basic law regarding persons with disabilities is the Law on Persons with Disabilities no 5378. This law intends that persons with disabilities should benefit from fundamental rights and freedoms, and to ensure their participation in social life under equal conditions with other individuals. Article 30 of Labour Law no 4857 regulates the details relevant to the liability of employers to employ persons 
with disabilities. Article 30 was regulated again in 2008, and new principles were established regarding the employment of persons with disabilities. In accordance with this, employers employing fifty or more employees in the workplace have to employ a specific number of persons with disabilities. When Article 30 of Labour Law is examined, it is observed that the straightforward quota method has been adopted regarding the employment of persons with disabilities. The quota determined within this scope is three percent for workplaces in the private sector, and four percent for workplaces in the public sector.

It is required that the following conditions are present for liability of the employer to employ persons with disabilities to arise : i) The workplace's inclusion in the scope of Labour Law, or Maritime Labour Law, ii) Employment of fifty or more employees in the workplace. In case of the presence of these conditions, the employers are required to employ persons with disabilities whose rate of disability is at least 40 percent.

Persons with disabilities should be employed through the Turkish Employment Agency. But the employer may also employ a person with disabilities through his own means. In this case, it is required to inform the Turkish Employment Agency, and to have the person with disabilities recorded at the Agency. An administrative fine is imposed on the employer acting against the liability of employing persons with disabilities.

Another method regarding the employment of persons with disabilities is the concept of sheltered employment. Briefly, this method is ensuring the employment of persons with disabilities - for whom it is difficult to bring them in business life - within the frame of special conditions. In this system, there are sheltered workplaces where the working environment is specifically arranged in order to ensure the employment of persons with disabilities. In Turkish Law, the principles of this subject have been regulated in the Law on Persons with Disabilities, and in a certain regulation issued on this subject. That Regulation first came into force in 2006, and it was renewed in 2013. Persons with disabilities who will be employed at sheltered workplaces, are not only persons with physical disabilities but persons with mental and psychological disabilities. In terms of acquiring the status of a sheltered workplace, some conditions have been sought by the Regulation. Above all, it is required that the workplace is one which holds the qualifications determined by the Regulation, and where at least eight persons with disabilities are employed. In addition, the ratio of the number of persons with disabilities who will be employed at a sheltered workplace to the number of total employees shouldn't be less than seventy five percent. In the Regulation, the physical conditions and equipment that the sheltered workplace has to have (safety, traffic safety, fire protection etc.) were also specified. A specific part of the remunerations 
of the persons with disabilities being employed at sheltered workplaces is paid by the government.

In Turkish law, amendments made in time in Article 30 of Labour Law being the basis of the liability of employing persons with disabilities, and especially the increase in incentives for the employers in private sector are deemed as proper regulations. Again, allowing the employers to find workers who will be employed by their own means is also among those steps which would facilitate employment. Certainly, considering the measures ensuring employment as incentives rather than a quota and fine method would be a more constructive approach. 


\section{İşverenin Engelli İşçi Çalıştırma Yükümlülüğü}

\section{Giriş}

Sosyal hayatta dezavantajlı gruplar arasında kabul edilen engellilerin ${ }^{1}$; eğitim ve sağlık hizmetlerine ulaşması, sosyal korumadan yararlanması kadar, istihdam edilebilmesi de son derece önemlidir. Zira işsizlik, "işsiz kalan tüm bireylerde faydasız bir insan olduğu hissini yaratmakta ve kişiyi moral çöküntü içine sokmaktadır"2. Engellilerin çalışma hayatına aktif olarak katılamaması kendilerinin ve ailelerinin ekonomik geleceğini tehlikeye düşürdüğü gibi, işsizliğin önemli etkilerinden olan toplumsal barışın zedelemesine de yol açar ${ }^{3}$. Engellilerin çalışma hayatında var olması ve bu varlığını sürdürmesi işsizlik riskinin yarattığı sosyal etkileri ortadan kaldıracağı gibi, çalışan engelliler, bu çalışmalarına dayanarak sosyal sigorta korumasından yararlanacağından, sosyal güvenlik bütçesinden engellilere yönelik yapılan harcamalarda da (sosyal yardım ve hizmetlerde) azalma olacaktır ${ }^{4}$. Bu nedenle, her birey gibi engelli bireylerin de işgücü alanında yer alması gerek bireysel gerek toplumsal açıdan birçok faydayı beraberinde getirmektedir.

Engellilere ilişkin politikalar, engellileri sosyal yardım kapsamında korumak şeklindeki pasif politikalarla başlamışken; bugün için gelinen nokta, engellilerin istihdama tam katılımının sağlanması yönündeki aktif politikalara dönüşmüştür. Ülkemizde de engellilerin istihdam edilebilirliğini sağlamak ve istihdam oranını arttırmak amacıyla çeşitli düzenlemeler yapılmış ve işverenlere bu yönde bir yükümlülük getirildiği gibi, teşvik uygulamaları da hayata geçirilmiştir. Kuşkusuz bu düzenlemelerin temel amacı, engellileri "kâğıt üstünde bir işyerinde çalışıyor göstermekten" çok; aktif olarak çalışma hayatına katılmalarını sağlamaktır. Engellilerin etkin ve sürdürülebilir istihdamı, engelli bireylere mesleki beceri kazandırılması ve istihdamın kalıcı nitelikte olmasını da içerir. Çalışmamızda, işyerinde belirli sayıda işçi çalıştıran işverenlerin engelli işçi çalıştırma yükümlülüğünün koşulları ve bu yükümlülüğe uymamanın sonuçları incelenmiş, engelli işçi çalıştırmanın teşviki amacıyla getirilen primlerin hazinece ödenmesi konusunda da ayrıca durulmuştur.

Esasen engelliliğe ilişkin çok sayıda tanım ve isimlendirme yapılmıştır. Ancak çalışmamızın konusu, engellilik yerine kullanılan diğer kavramları tartışmak veya engelliliğe ilişkin yapılan tüm tanımlamaları ortaya koymak değildir. Bu nedenle terminoloji olarak, hukukumuzda da kabul edilen "engelli" kavramı benimsenmiş, engelliliğe ilişkin yapılan çeşitli tanımlamalara çalışma içinde yer verilmiştir.

William H. Beveridge, Full Employment in A Free Society (2nd edition, 1960) 19.

Kenan Tunçomağ, 'Sakat ve Eski Hükümlü Çalıştırma Yükümü' (1974) 40(4) İstanbul Üniversitesi Hukuk Fakültesi Mecmuasi 375, 376.

4 Ömer Ekmekçi, 'Yeni Tüzük Hükümleri Uyarınca Sakat İşçi Çalıştırma Yükümü' (1987) $(4,5,6)$ İstanbul Barosu Dergisi (Sakat İşçi Çalıştırma) 309, 310. Primli ve primsiz sistemde engellilere yapılan yardımlar ve genel olarak engellilerin sosyal güvenliği için bkz Canan Ünal, Özürlülerin Sosyal Güvenlik Haklarl (Beta 2012) 87-169. 


\section{Engelli İşçi Çalıştırma Yükümlüğüne İlişkin Mevzuat Hükümlerine Uluslararası Sözleşmeler Karşısında Genel Bir Bakış}

\section{A. Genel Olarak Engellilerin İstihdama Katılma Oranları}

Uluslararası Çalışma Örgütü (ILO) raporlarında, ağır ya da hafif engelli bireylerin, dünya nüfusunun yüzde 15 'ini oluşturduğu ve bunların yüzde 80 'inin de aktif çalışma yaşında olduğu; engelli bireylerin ve özellikle engelli kadınların; iş dünyasında firsat eşitliği konusunda ciddi sorunlarla karşılaştığı, engelli olmayan bireylerle kıyaslandığında daha fazla işsizlik ve ekonomik hareketsizlik yaşadıkları açıklanmıştır5. Dünya Sağlık Örgütü’nün (WHO) 2011 tarihli ve oldukça geniş kapsamlı raporunda (World Report on Disability); 51 ülkenin verileri incelendiğinde, istihdama katılan engelli erkeklerin oranının yüzde 52, engelli kadınların oranının yüzde 19 olduğu; Ekonomik İşbirliği ve Kalkınma Örgütü (OECD) ülkelerinde ise engelli olmayanların istihdama katılım oranı yüzde 75 iken, bu sayının engellilerde yüzde 44'e düştüğü tespit edilmiştir ${ }^{6}$. Avrupa Birliğinde ise Avrupa Topluluğu İstatistik Ofisi (EUROSTAT) verileri incelendiğinde, aktif çalışma yaşındaki engellilerin istihdam oranlarının yüzde 47 olduğu görülmektedir?

Ülkemizdeki duruma gelince, Türkiye'de engelli bireylerin yaş, cinsiyet, şehir bazında dağılımına ilişkin son araştırma Türkiye İstatistik Kurumu (TÜIK) tarafindan gerçekleştirilen 2011 tarihli Nüfus ve Konut Araştırması' ırr $^{8}$. Buna göre, “en az bir engeli olan nüfusun oranı yüzde 6.9 (4.876.000 kişi)'dur. Erkeklerde yüzde 5.9 olan bu oran, kadınlarda yüzde 7.9'dur". Sağlık Bakanlığı ile Aile, Çalışma ve Sosyal Hizmetler Bakanlığı'nın veri tabanlarından elde edilerek oluşturulan Ulusal Engelli Veri Tabanında kayıtlı olan engelli sayısı ise 2019 yılının ilk yarısı itibariyle 2.461.828'dir'. TÜIK' in 2019 yılı Mayıs ayı verilerine göre ülkemizde genel olarak işgücüne katılma oranı yüzde $52.9^{\prime}$ dur $^{10}$. Engellilerin istihdamdaki oranına ilişkin ulaşılabilen en güncel resmi istatistik olan 2011 Nüfus ve Konut Araştırması'na göre, engellilerin istihdamdaki oranı yüzde 22.1'dir. Avrupa Birliği ve OECD verileriyle kıyaslandığında, bu sayı düşüktür.

Çalışmamızın ası1 konusunu oluşturan, 4857 sayılı İş Kanunu ${ }^{11}$ madde 30 uyarınca işçi çalıştırma yükümlügüne ilişkin istatistikler ise Türkiye İş Kurumu (İŞKUR) tarafından yayınlanmaktadır. Bu istatistiklere göre 2019 yılı Haziran ayı itibariyle,

ILO, < https://www.ilo.org/global/topics/disability-and-work/WCMS_475650/lang--en/index.htm> Erişim Tarihi 8.9.2019. WHO, World Report on Disability (2011) 237.

EUROSTAT, <https://ec.europa.eu/eurostat/documents/3888793/6802087/KS-TC-14-007-EN-N.pdf/5c364add-66704ac9-87c7-9b8838473a7b> Erişim Tarihi 8.9.2019.

8 TÜIK < https://biruni.tuik.gov.tr/yayin/views/visitorPages/index.zul> Erişim Tarihi 7.9.2019.

9 Aile, Çalışma ve Sosyal Hizmetler Bakanlığı, Engelli ve Yaşlı İstatistik Bülteni (2019)<https://ailevecalisma.gov.tr/ media/9085/buelten-haziran2019-son.pdf > 16, Erişim Tarihi 7.9.2019.

10 TÜiK < http://www.tuik.gov.tr/UstMenu.do?metod=temelist> Erişim Tarihi 7.9.2019.

11 RG 10.6.2003/25134. 
engelli işçi çalıştırmakla yükümlü olunan işyeri ve işçi sayısı kamuda 1.334 işyerinde 17.106; özel sektörde 17.702 işyerinde 110.554 işçidir. Engelli çalıştırmakla yükümlü bu işyerlerinde çalışan engelli sayısı ise kamuda 15.542 iken, özel sektörde 97.028'dir. Görüldüğü gibi kamuda 4.253, özel sektörde ise 20.642 kişilik açık bir kontenjan sayısı bulunmaktadır. Böylece, (engelli işçi çalıştırmakla yükümlü olunmamasına rağmen İŞKUR aracılığıyla engelli işçi çalıştıran işyerlerinde çalışan 8.808 işçi de dikkate alındığında), yaklaşık 136 bin engelli işçinin, kamu ve özel sektör işyerlerinde İş Kanunu madde 30 gereğince istihdam edildiği görülmektedir ${ }^{12}$.

Tüm bu sayısal verilerin gösterdiği üzere, dünyada ve ülkemizde, engellilerin işgücüne katılım oranı yüksek değildir. Bu nedenle, birçok uluslararası belgede, engellilere her alanda eşit haklar tanınması gerektiği düzenlenerek; engellilerin çalışma hakkının korunması üzerinde ayrıca durulmuştur. Engellilerin uygun bir işte çalışması ve işe devamlarının güvence altına alınması, bu sözleşmelere taraf devletlere getirilmiş önemli yükümlülüklerden olmuştur. Ülkemizde de, özellikle 2005 yılından itibaren, engellilere yönelik politikaların geliştirilmesinde önemli adımlar atılmıştır.

\section{Engelli İstihdamına Yönelik Temel Uluslararası Düzenlemeler}

Engellilerinçalışmahayatına dahilolmalarıSanayiDevrimi’ndensonragerçekleşmiş ancak işgücüne olan ihtiyacın arttığı bu dönemde dahi engelliler, çoğunlukla istihdamın dışında tutulmuştur ${ }^{13}$. Dünya savaşlarından sonra engelli sayısındaki artış ve bu durumun yol açtığ 1 sorunlar nedeniyle bu konu ülke gündemlerinde yer almaya başlamıştır ${ }^{14}$. İnsan hakları konusunda gelişen ve olgunlaşan anlayış dezavantajlı grupların da özel olarak korunması düşüncesini doğurmuş ve uluslararası belgelerde engellere yönelik çeşitli esaslar kabul edilmiştir. Kuşkusuz bu düzenlemelerden ilki olarak, 1948 tarihli İnsan Hakları Evrensel Beyannamesi’nin zikredilmesi gerekir. Beyannamenin 25. maddesinde, herkesin işsizlik, hastalık, engellilik, dulluk, yaşl11ık gibi kendi kontrolü dışında gerçekleşen ve geçim eksikliği yaratan risklere karşı korunması gerektiği ifade edilmiştir.

Evrensel Beyannamede yer alan bu düzenlemeyi Birleşmiş Milletler'in çeşitli sözleşmeleri takip etmiştir. Bu sözleşmelerden konu bakımından üzerinde durulması gereken ilk sözleşme 1966 yılında kabul edilip 1976 yılında yürürlüğe giren Ekonomik, Sosyal ve Kültürel Haklar Uluslararası Sözleşmesi'dirr' ${ }^{15}$. Sözleşme, Türkiye tarafından 2000 yılında imzalanmış ve 2003 yılında onaylanması üzerine Resmi Gazete'de ${ }^{16}$ yayınlanmıştır. Sözleşme Türkiye bakımından 23 Aralık 2003

12 İşKUR < https://www.iskur.gov.tr/kurumsal-bilgi/istatistikler/> Erişim Tarihi 8.9.2019.

13 Mustafa Şen, ‘Türkiye'de Engellilere Yönelik İstihdam Politikaları' (2018) 8(2) Sosyal Güvenlik Dergisi 129, 130.

14 İbrahim Subaşı, 'İş Hukukunda Özürlülerin Durumu' (2011) Prof. Dr. Tankut Centel’e Armağan (İstanbul Üniversitesi Yayını 2011) 477,477.

15 Tam metin için bkz < https://www.ohchr.org/EN/ProfessionalInterest/Pages/CESCR.aspx> Erişim Tarihi 3.9.2019.

16 RG 11.8.2003/25196. 
tarihinden itibaren yürürlüğe girmiştir. Bu Sözleşmeye göre; taraf devletler, herkesin özgürce seçtiği ya da benimsediği bir işte çalışarak hayatını kazanma fırsatına sahip olma hakkını içeren çalışma hakkını tanır ve bu hakkı korumak için uygun girişimlerde bulunur (madde 6). Yine Sözleşmeye taraf olan devletler, tüm işçilerin adil bir biçimde, herhangi bir ayrım gözetmeksizin eşit işe eşit ücret ilkesiyle çalıştırılmalarını güvence altına alacaktır (madde 7).

Konu bakımından öneme sahip olan ikinci sözleşme ise Engelli Kişilerin Haklarına İlişkin Uluslararası Sözleşme' dir ${ }^{17}$. Sözleşme, BM Genel Kurulu tarafindan 2006 tarihinde kabul edilmiş ve 2008 tarihinde yürürlüğe girmiştir. Türkiye, Sözleşmeyi 2007 yılında imzalamış ve 2009 yılında Sözleşmenin onayına ilişkin Bakanlar Kurulu kararı, Resmi Gazete'de ${ }^{18}$ yayınlanmıştır. Sözleşmenin Türkiye bakımından yürürlüğe girdiği tarih ise 28 Ekim 2009'dur. Türkiye bu Sözleşmeye herhangi bir çekince koymamış veya beyanda bulunmamıştır. Sözleşmenin "Çalışma ve istihdam" başl1kl1 27. maddesi; "Taraf Devletler, engellilerin diğer bireylerle eşit koşullar altında çalışma hakkına sahip olduğunu kabul eder" hükmü ile başlamaktadır. Maddede, çalışma hakkının, "engellilerin, açık, bütünleştirici ve erişilebilir bir iş piyasası ve çalışma ortamında serbestçe seçtikleri bir işle hayatlarını kazanmaları firsatını" da içerdiği açıkça vurgulanmıştır. Buna göre taraf devletler, işe alım ve istihdam edilme koşullarında, istihdamın sürekliliği, kariyer gelişimi ve sağlıklı ve güvenli çalışma koşulları dahil olmak üzere, istihdama ilişkin her hususta, engelliliğe dayalı ayrımcılığı yasaklayacak, engellilerin iş ve sendikal haklarını diğer bireylerle eşit koşullar altında kullanabilmelerini sağlayacak ve çalışma hayatında engellilerin istihdam olanaklarının ve kariyer gelişiminin desteklenmesine ve engellilerin iş aramasına veya işe başlamasına, çalışmaya devam etmesine ve işe geri dönmesine yardım edecektir. Bunun yanında taraf devletler; engellileri kamu sektöründe istihdam edecek ve olumlu eylem programları, teşvikler ve diğer tedbirleri de içerebilecek uygun politika ve önlemlerle, engellilerin özel sektörde istihdam edilmelerini destekleyecektir. Türkiye tarafından onaylanarak hukukumuzun bir parçası olan bu Sözleşme; engellilere ilişkin getirdiği istihdam politikası hükümleri gibi diğer hükümleri itibariyle, devletlere önemli yükümlülükler getiren oldukça kapsayıcı ve detaylı bir sözleşmedir.

Bu kapsamda son olarak ILO'nun 1983 tarihli ve 159 sayılı Sakatların Mesleki Rehabilitasyon ve İstihdamı Hakkındaki Sözleşmesi'ne ${ }^{19}$ yer verilmelidir. Sözleşme, Türkiye tarafından onaylanarak ${ }^{20} 20$ Haziran 2000 tarihi itibariyle yürürlüğe girmiştir.

\footnotetext{
7 Tam metin için bkz $<$ https://www.un.org/development/desa/disabilities/convention-on-the-rights-of-persons-withdisabilities. > Erişim Tarihi 3.9.2019.

18 RG 14.7.2009/27288.

19 Tam metin için bkz <https://www.ilo.org/ankara/conventions-ratified-by-turkey/WCMS_377302/lang--tr/index.htm> Erişim Tarihi 3.9.2019.

20 RG 10.7.1999/23751.
} 
Sözleşmeye göre engelli terimi, "uygun bir iş temini muhafazası ve işinde ilerlemesi hususundaki beklentileri, kabul edilmiş fiziksel veya zihinsel bir özür sonucu önemli ölçüde azalmış olan bir bireyi" ifade eder. Bu sözleşmede üyelerin, engelliler bakımından bir istihdam politikası geliştirmesinin altı çizilerek, bu politikanın engelli işçiler ile engelli olmayan işçiler arasında firsat eşitliği ilkesine dayanması gerektiği belirtilmiştir.

Uluslararası sözleşmelerde getirilen bu esaslara rağmen, engellilerin tüm dünya genelinde çalışma hayatında yeterince rol alabildiği söylenemez. Bu sonuç, devletlerin bu konuda etkin uygulamaları hayata geçirememesinden kaynaklandığı gibi işverenlerin engelli işçi çalıştırmak konusundaki olumsuz yaklaşımından da kaynaklanmaktadır. Kimi zaman da esasen çalışma hayatında yer almak isteyen engelliler, karşılaşabilecekleri zorlukları düşünerek bu isteklerinden vazgeçmekte ve iş aramaktan çekinmektedir. Nitekim, uluslararası çalışmalarda; topluma tam katılımın sağlanmasında, eğitim ve istihdamın en önemli iki unsur olarak karşımıza çıktığı, engellilerin özellikle işgücü alanına katılmasının engelli olmayanlara göre iki kat daha zor olduğu, çalışan engellilerin ise daha çok yarı zamanlı veya serbest meslek esasına göre çalıştığ 1 , engelli ailelerinin görece daha yüksek bir yoksulluk riski altında bulunduğu tespit edilmiştir ${ }^{21}$. Benzer olarak, uygun olmayan ortamda çalışmanın, engelli olmayanlara göre engellileri daha çok etkilediğinden (daha az üretken yaptığından); bu kimselerin işyerine ulaşmasının çoğu zaman daha maliyetli olmasına kadar engellilerin çalışma hayatının bir parçası olması konusunda yaşadığ1 zorluklar sıralanmıştı²2. ILO'nun 2014 - 2017 yıllarını kapsayan strateji ve eylem planında da (Disability Inclusion Strategy and Action Plan 2014-17), engelli bireylerin istihdamını etkileyen tüm olumsuz unsurların ortadan kaldırılmasına yönelik çalışmalara devam edileceği, özellikle bu alanlara odaklanan stratejik öneme sahip kuruluşlarla işbirliği yapılacağı belirtilmiştir ${ }^{23}$.

\section{Ulusal Düzenlemeler}

Uluslararası sözleşmelerin yanında, engellilerin istihdamına ilişkin kanun hükümlerine yer vermeden önce bu hükümlerin de temel dayanağı olan Anayasa üzerinde durulmalıdır. Anayasa'nın birçok maddesi konu ile doğrudan veya dolaylı olarak ilgilidir. Kuşkusuz bu maddelerden ilki, "Herkes yaşama, maddi ve manevi varlğ̆ını koruma ve gelişstirme hakkina sahiptir" hükmünü içeren 17. maddedir. Esasen bütün temel hakların, maddi ve manevi varlı̆̆ koruma ve geliştirme hakkından doğan temel özgürlük hakkının bir sonucu olduğunu söylemek mümkündür.

\footnotetext{
Valentina Stoevska, 'Disability Statistics - Labour Market Characteristics of Persons with Disabilities' (2018) 20th International Conference of Labour Statisticians 10 - 19 October 2018, Geneva (ILO, 2018) 2.

22 Ayrıntılı açıklamalar için bkz WHO (n 6) 236 ff.

23 ILO, <https://www.ilo.org/wcmsp5/groups/public/---ed_emp/---ifp_skills/documents/genericdocument/wcms_370772. pdf $>$ Erişim Tarihi 8.9.2019.
} 
$\mathrm{Bu}$ hükümden sonra ele alınması gereken düzenlemeler, Anayasa'nın 3. bölümünde yer alan ve pozitif statü hakkı olarak kabul edilen, sosyal ve ekonomik haklar ve ödevlerle ilgilidir. Bu haklardan ilki, 49. maddede açıklanan çalışma hakkı ve ödevidir. Buna göre, "Çalışma, herkesin hakkı ve ödevidir. Devlet, çalışanların hayat seviyesini yükseltmek, çalışma hayatını geliştirmek için çalışanları ve işsizleri korumak, çalışmayı desteklemek, işsizliği önlemeye elverişli ekonomik bir ortam yaratmak ve çalışma barışını sağlamak için gerekli tedbirleri alır". Anayasamızda, çalışma, ayrım yapılmaksızın tüm bireyler için hem bir hak hem de bir ödev olarak görülmüştür. Bir başka ifadeyle, çalışma hakkının özelliği, zorla çalıştırma yasağ (madde 18) karşısında isteğe bağlı olarak herkese tanınmasıdır ${ }^{24}$. Ancak, çalışma hakkının kullanılması tek başına bu hakkın öznesine değil, bazı dış etmenlerin de gerçekleşmesine bağlıdır. Bu noktada da devlete, çalışma ortamını sağlama ödevi verilmiştir. Esasen devletin bu ödevi, işsizliği önlemekle yakından ilgili olduğu gibi $^{25}$, işsiz kalanlara yardım edilmesi ve belli zorunlu işleri yaratmak için gerekli önlemlerin alınmasını da içerir ${ }^{26}$.

Devletin bu ödevini gerçekleştirmesi, özellikle istihdam konusunda birçok zorluk yaşayan engelliler açısından oldukça önemlidir. $\mathrm{Bu}$ nedenle devletin, bu bireyler için özel olarak önlemler alması ve çalışma ortamını sağlaması gerekir. Nitekim Anayasa'nın 50. maddesinde kimsenin, gücüne uymayan işlerde çalıştırılamayacağ vurgulanmış ve "bedeni ve ruhi yetersizliği olanlar çalışma şartları bakımından özel olarak korunurlar" düzenlemesi getirilmiştir (fikra 1 ve 2). Bunun yanında, "Devlet, sakatların korunmalarını ve toplum hayatına intibaklarını sağlayıcı tedbirleri alır" biçimindeki 61. madde (fikra 2) hükmüyle de sosyal güvenlik bakımından özel olarak korunması gerekenler arasında engelliler de sayılmıştır ${ }^{27}$.

Engellilerin, temel hak ve özgürlüklerden faydalanmasını teşvik ve temin ederek toplumsal hayata diğer bireylerle eşit koşullarda tam ve etkin katılımlarının sağlanması ve engelliliği önleyici tedbirlerin alınması için gerekli düzenlemelerin yapılmasını sağlamak amacıyla çıkarılan ve engellilere yönelik en temel kanun olarak kabul edebileceğimiz kanun; 5378 sayılı Engelliler Hakkında Kanun’dur²8. Bu Kanun’un

\footnotetext{
Ayrıntılı açıklamalar için bkz. Cahit Talas, 'Çalışma Hakkı ve Türkiye’deki Durum’ (1991) XLVI(1) Ankara Üniversitesi Siyasal Bilgiler Fakültesi Dergisi 407,407; Murat Şen, ‘İnsan Hakları Bağlamında Çalışma Hakkı’ (2013) 2(2) Marmara Üniversitesi Hukuk Fakültesi Dergisi 13,20.

25 Talas (n 24) 406.

26 Şen (n 24) 19.

27 Hemen belirtmek gerekir ki, hukukumuzda önce, 572 sayılı Bazı Kanunlarda Değişiklik Yapılmasına İlişkin Kanun Hükmünde Kararname (RG 6.6.1997/23011 Mükerrer) ile 1475 sayılı İş Kanunu'nun 25. maddesinin de dahil olduğu kimi düzenlemelerde yer alan "sakat" ibaresi yerine "özürlü" ibaresi getirilmiş; daha sonra 2013 yıllnda kabul edilen, Kanun ve Kanun Hükmünde Kararnamelerde Yer Alan Engelli Bireylere Yönelik İbarelerin Değiștirilmesi Amacıyla Bazı Kanun ve Kanun Hükmünde Kararnamelerde Değișiklik Yapılmasına Dair 6462 sayılı Kanun'la (RG 3.3.2013/28636) mevzuatımızda geçen "özürlü” ibareleri "engelli” olarak düzeltilmiştir. Ancak, Anayasa'nın bu maddesinde yer alan "sakat" ifadesi varlığını sürdürmüştür.

28 RG 7.7.2005/25868.
} 
14. maddesi, engellilerin istihdamına ilişkin hükümlere ayrılmışıır' ${ }^{29}$. Maddede yer alan esaslar; -engellilerin sürdürülebilir istihdamı için gerekli tedbirlerin alınması, -işe başvuru, önerilen çalışma süreleri, sağlıklı ve güvenli çalışma koşulları da dahil istihdama ilişkin engelliliğe dayalı ayrımcılık yapılmaması, - çalışan engellinin aleyhine, engelinden dolayı diğer kişilerden farklı muamele yapılmaması, - işverenler tarafından engellilerin karşılaşacakları güçlük ve engelleri kaldırmak üzere işyerlerinde makul düzenlemelerin yapılmasının zorunlu olması şeklinde sıralanabilir.

Geçmişten günümüze iş kanunları incelendiğinde, engelli istihdamına ilişkin olarak işverenlere doğrudan kanuni bir yükümlülük getiren ilk hükmün, 854 sayılı Deniz İş Kanunu'nda ${ }^{30}$ yer aldığ 1 tespit edilmektedir. Kanuna göre, işverenler, işyerlerinde İş Kanunu'nun bu konuda koyduğu hükümler, esaslar, ölçütler ve şartlara göre engelli gemi adamı çalıştırmak zorundadır (madde 13). Deniz İş Kanunu yürürlüğe girdiğinde atıf yapılan İş Kanunu hükmü bulunmamaktayken, bu kanundan kısa bir süre sonra 931 sayılı İş Kanunu'nun ${ }^{31}$ yürürlüğe girmesiyle, hukukumuzda engelli işçi çalıştırma yükümlüğ̈nün esasları ilk kez düzenlenmiştir (m.25). Buna göre, yüz işçiye kadar işçi çalıştıran işverenler her tam elli işçiye karşıllık bir engelli (Kanunun ifadesiyle sakat), işçi sayısının yüzden fazlası için her yüz işçiye karşılık iki engelli çalıştırmakla yükümlüdür. Engellilerin çalıştırılacağı işlerin, beden ve ruh durumlarına uygun olması gerekir. Kısa bir süre yürürlükte kalan bu kanundan sonra yürürlüğe giren 1475 sayılı İş Kanunu'nun ${ }^{32} 25$.maddesinde de engellilerin istihdamına yönelik aynı düzenleme varlığını sürdürmüştür ${ }^{33}$. Bu maddeye dayanılarak önce, Sakatların ve Eski Hükümlülerin Çalıştırılmaları Hakkında Yönetmelik ${ }^{34}$, sonra da Sakatların İstihdamı Hakkında Tüzük yürürlüğe girmiştir ${ }^{35}$.

Nihayet, bugün için 4857 sayılı İş Kanunu'nun 30. maddesi, işverenlerin engelli işçi çalıştırma yükümüne ilişkin detayların düzenlendiği hüküm olarak karşımıza çıkmaktadır. Söz konusu 30. madde, 2008 yılında bir torba kanunla (5763 say1lı Kanun) yeniden düzenlenmiş ve önceki iş kanunlarından değişik bazı esaslar getirilmiştir. Öte yandan bu maddeye dayanılarak çıkartılan Özürlü, Eski Hükümlü ve Terör Mağduru İstihdamı Hakkında Yönetmelik ${ }^{36}$ yerine de Yurtiçinde İşe Yerleştirme Hizmetleri Hakkında Yönetmelik ${ }^{37}$ yürürlüğe girmiştir.

\footnotetext{
29 Kanunun temel esasları hakkında bkz Gülsevil Alpagut 'Özürlüler Hakkında Kanun ve Özürlü Çalıştırma Zorunluluğu Konusunda Mevzuattaki Son Değişiklikler’ (2005) (Ekim) Mercek Dergisi (Son Değişiklikler) 152,153 ff.

30 RG 29.4.1967/12586.

31 RG 12.8.1967/12672.

32 RG 1.9.1971/13943.

33 Ayrıntılı açılamalar için Tunçomağ (n 3$) 377$ ff; Ekmekçi, Sakat İşçi Çalıştırma (n 4) 310-311; M. Fatih Uşan, İ̧̧ Hukukunda Sakat İstihdamı (Türkiye Sağlık İşçileri Sendikası 1999) 210 ff.

34 RG 21.1.1972/14079.

RG 16.3.1987/19402.

6 RG 24.3.2004/25412.

37 RG 25.4.2009/27210.
} 
Hemen belirtilmelidir ki, 30. maddenin ve bu maddeye aykırılık nedeniyle idari para cezasının düzenlendiği 101. maddenin, Anayasa'ya aykırılığı iddiasıyla açılan dava, Anayasa Mahkemesi tarafından reddedilmiştir ${ }^{38}$. Engelli işçi çalıştırmaması üzerine idari para cezasına çarptırılan işverenin açtığı iptal davasını gören idare mahkemesi, hükmü Anayasa Mahkemesi’ne taşımıştır. İdare mahkemesi gerekçesinde, engelli işçi çalıştırma yükümünün sosyal devlet ilkesi gereği Devlete ait olduğunu, bunun yükünün özel teşebbüslere yükletilmemesi gerektiğini, ayrıca hükmün sözleşme yapma hürriyetine, işverenler için bir angarya getirdiği için de angarya yasağına aykırı bulunduğunu açıklamıştır. Yüksek Mahkeme ise isabetli olarak, engelli işçi çalıştırma yükümüne ilişkin kuralın, dezavantajlı grupları koruduğu yani sosyal amaçları gözettiği ve sosyal devlet ilkesinin bir sonucu olduğu, ayrıca kuralda özel kesim açısından bir ölçüsüzlük de bulunmadığı gerekçesiyle itirazı reddetmiş, hükmün angarya yasağıyla ilgili bulunmadığını da ayrıca belirtmiştir ${ }^{39}$. Kanımca da hükümde Anayasa'ya aykırılık söz konusu değildir. Yukarıda açıklandığı üzere, engellilerin istihdamına yönelik politikalar geliştirilmesi, uluslararası belgelerde ve iç hukukumuzda kabul edilmiş bir amaçtır. Bu amacın temelinde insan haklarının korunması, geliştirilmesi ve sosyal devlet ilkesi yatar. Engellilere yönelik politikalar; pasif biçimde, yalnızca onları bir sosyal yardım objesi olarak görerek korumaya ve ihtiyaçlarını gidermeye yönelik olmamalı aksine aktif politikalarla, engellilerin kendi mesleki becerilerini kazanıp çalışma hayatına dahil olmaları, kendi çalışmaları nedeniyle gelir sahibi olmalarının sağlanması biçiminde olmalıdır. Bunun gerçekleşebilmesi de istihdamda etkin olarak yer almaktan geçer. Bu nedenle makul düzenlemelerle, işverenlere belirli oranda engelli işçi çalıştırma yükümü getirilmesi mümkündür. Öte yandan bunun bir "yük" olarak değerlendirilmesi de yerinde değildir. İşveren tarafından uygun şartlarda çalıştırılan engelliler, engelli olmayan işçiler gibi, işverenin ve giderek tüm ülkenin ekonomik yararına iş görür.

Engellilerin istihdamı konusuna, yasal düzenlemelerin yanında kalkınma planlarında da yer verilmiştir. Nitekim 11. Kalkınma Planı'nın (2019-2023) "İstihdam ve çalışma hayatı" başlıklı bölümde; engellilerin işgücüne katılımı ve istihdamının artırılacağı, engellilerin meslek edinmesine yönelik uzaktan eğitim programları ile engellilerin işgücüne katılımını ve istihdam edilebilirliğini artırmak için genel ve mesleki eğitim, mesleki rehabilitasyon, kendi işini kurma hibe desteği ve iş ve meslek danışmanlığı hizmetlerinin geliştirileceği, engellilere yönelik istihdam olanakları ve engelli istihdamına ilişkin teşvikler konusunda özel sektör işverenlerinin bilinçlendirilmelerinin sağlanacağı ve iş ve meslek danışmanlarının niteliklerinin engellilere daha iyi bir hizmet sunabilecek şekilde geliştirileceği üzerinde durulmuştur.

\footnotetext{
8 Anayasa Mahkemesi, 101/126, 19.6.2008, RG 19.11.2008/27059.

39 Kararı inceleyen Tamer Bozkurt, ‘Anayasa Mahkemesi’nin 4857 Sayılı İş Kanunu’ndaki Engelli ve Eski Hükümlü Çalıştırma Zorunluluğunun Anayasa'ya Uygun Olduğuna Dair Verdiği Karar Üzerine Düşünceler' (2009) (2) Ankara Barosu Dergisi 98,105.
} 


\section{Engelli İşçi Çalıştırma Yükümlülüğünün Esasları}

\section{A. Kabul Edilen İstihdam Yöntemi}

Engellilerin istihdamına yönelik yöntemler çok çeşitli olabilir. Bunlardan, kişisel çalışma yöntemi, evde çalışma yöntemi, kooperatif usulü çalışma yöntemi ve işverenin engelliyi bir zorunluluk olmaksızın işe alması yöntemleri bir kenara bırakılırsa; istihdamı sağlayıcı en temel üç yöntemin, belirli sayıda engelli istihdamını zorunlu kılan kota sistemi, belirli iş alanlarının yalnızca engellilere tahsis edilmesi ve her iki sistemle birlikte uygulanabilen koruyucu istihdam olduğu söylenebilir" ${ }^{40}$. İş Kanunu'nun "İşverenler, elli veya daha fazla işçi çalıştırdıkları özel sektör işyerlerinde yüzde ü̧̧ engelli, kamu işyerlerinde ise yüzde dört engelli ... işşiyi ... meslek, beden ve ruhi durumlarına uygun işlerde çalıştırmakla yükümlüdürler." hükmü karşısında, hukukumuzda engelli istihdam yöntemlerinden kota yönteminin benimsendiği görülmektedir ${ }^{41}$.

Kota yönteminin; çeşitli ülkelerde "doğrudan doğruya kota" (straightforward quota) yöntemi olarak, yani işverenlere engelli işçi çalıştırma yönünde bir zorunluluk getirilmesi şeklinde uygulandığı gibi kimi zaman da engelli işçi çalıştırmak yerine, seçimlik bir hak gereğince, bu amaçla kurulmuş bir fona ödeme yapılması olarak uygulandığı da bilinmektedir. Buna göre, 30. maddenin işverenlere doğrudan bir yükümlülük getirmesi nedeniyle kanunun kabul ettiği sistemin "doğrudan doğruya kota" olduğu belirtilmelidir. Ancak, aşağıda yer verileceği üzere Engelliler Hakkında Kanun'un 14.maddesine dayanılarak çıkartılan Korumalı İşyerleri Hakkında Yönetmelik esasları gereğince, ülkemizde engellilere yönelik "koruyucu istihdam yöntemi” (sheltered employment) de uygulanmaktadır.

Kota kapsamında 30. maddede belirlenen kontenjan, özel sektör işyerleri için yüzde üç, kamu işyerleri için yüzde dörttür. 1475 sayılı Kanun’da engelliler için yüzde üç, eski hükümlüler için yüzde üç ve terör mağdurları için yüzde iki olmak üzere ayrı kontenjanlar öngörülmesine rağmen, 4857 sayılı İş Kanunu'nun 30. maddesinin 5763 say1l Kanunla değiştirilmeden önceki halinde ve eski yönetmelikte bu oran, işyerinde çalışan toplam işçi sayısının yüzde altısı olarak tespit edilmiş ve engelliler için belirlenen oranın toplam oranın yarısından az olamayacağı belirlenmiştir. İşverenlerin zorunlu olarak çalıştıracağı işçi sayısının her yıl Bakanlar Kurulu tarafından belirlenerek hesap edileceği de düzenlenmiştir. $\mathrm{Bu}$ oranın her yıl tespit edilmesini günün koşullarına göre istihdamın yönlendirilmesi bakımından yerinde bulan kimi görüşlere rağmen ${ }^{42}$, kanun değişikliğiyle bu oranlar sabit olarak belirlenmiştir.

\footnotetext{
40 Bu yöntemler ve çeşitli ülke uygulamaları için bkz. Uşan (n 33) 87 ff; Şen (n 13) 138. Koruyucu istihdam modeli hakkında açıklamalar için bkz IV.

41 Gülsevil Alpagut ‘4857 Sayılı Yasa’da Özürlü, Eski Hükümlü ve Terör Mağduru Çalıştırma Yükümlülüğü’ (2004) (Nisan) Mercek Dergisi (Özürlü Çalıştırma) 118,119.

42 Alpagut, Son Değişiklikler (n 29) 159, yazara göre, örneğin eski hükümlü veya terör mağduru sayısında yıllar içinde azalma olması halinde engelli oranının yüksek tutulması, böylece gruplar arasında değişebilecek iş gücü arzına bağlı olarak istihdama yön verilmesi mümkündür. Aynı yönde A. Eda Manav, 'İşverenin Özürlü, Eski Hükümlü ve Terör Mağduru Çalıştırma Zorunluluğu' (2006) 10(1-2) Gazi Üniversitesi Hukuk Fakültesi Dergisi 137,157.
} 


\section{B. Engelli İşçi Çalıştırma Yükümlülüğünün Uygulama Alanı: İş K. Ve Deniz İş K. Kapsamına Giren Ve Elli Veya Daha Fazla İşçi Çalıştırılan İşyerleri}

\section{1. İşyerinin İş Kanunu veya Deniz İş Kanunu'nun Kapsamına Girmesi}

Engelli işçi çalıştırma yükümü İş K.'nda düzenlendiğinden, yükümlülüğün uygulanacağı işverenler, madde 4 gereğince İş Kanunu'nun kapsamına giren işverenlerdir. Öte yandan İş K.'nun kapsamına girmekle birlikte, süreksiz işlerde yapılan iş sözleşmelerine, konuyu düzenleyen 10. maddenin açık hükmü karşısında 30. maddenin uygulanması mümkün değildir. Yukarıda yer verildiği gibi, Deniz İş Kanunu'nun 13. maddesinde de açıkça engelli gemi adamı çalıştırma yükümlüğü düzenlendiğinden ${ }^{43}$, 1. madde gereği Kanunun kapsamına giren işverenler de bu yükümlülüğe tabidir. İş Kanunu ve Deniz İş Kanunu kapsamına giren işverenlerin, özel sektör ya da kamu işvereni olması yükümlülüğün doğması bakımından bir fark yaratamamakta, ancak özel sektör işvereni bakımından çalıştııılacak işçi sayısı daha düşük olmaktadır. Yurt İçinde İşe Yerleştirme Hizmetleri Hakkında Yönetmelik'in 10. maddesinde, bankalar, borsalar, kamu kurum ve kuruluşlarının vizeye tabi olmadan işçi çalıştıran eğitim ve sosyal tesisleri gibi bazı yerlerin işverenlerinin, özel sektör işvereni olarak değerlendirileceği sıralanmıştır (fikra 2).

Basın İş Kanunu'nda ${ }^{44}$, engelli işçi çalıştırılmasına yönelik bir düzenleme bulunmamaktadır. $\mathrm{Bu}$ nedenle konu öğretide tartışma konusu olmuştur. Bir görüşe göre, İş Kanunu'nun kapsamı dışında tutulan işlerde açıkça basın işi sayılmadığından, bu işlerin görüldüğü işyerlerinde de engelli işçi çalıştırılmak zorundadır ${ }^{45}$. Ancak çoğunluk görüş, Basın İş Kanunu ile olan bu farkı anlamsız, çelişkili ve makul bir açıklamadan uzak bulsa da Basın İş Kanunu'nda bu yönde açık bir düzenleme olmaması nedeniyle basın işverenlerinin engelli çalıştırma yükümlülüğünün bulunmadığı yönündedir ${ }^{46}$. Bu görüşe göre, Kanunda düzenlemenin bulunmadığı her durumu bir boşluk olarak kabul etmek mümkün değildir. Kanun koyucunun herhangi bir hüküm sevk etmemesi, basın işverenleri açısından böyle bir zorunluluk getirmemesi demektir. Bir an için kanunda boşluk olduğu düşünülse bile, bu boşluğa uygulanacak olan kanun, Türk Borçlar Kanunu'dur. Oysa Türk Borçlar Kanunu'nun hizmet sözleşmesini düzenleyen hükümlerinde de böyle bir kural yer almamaktadır ${ }^{47}$.

\footnotetext{
43 Deniz İş K.'nda engelli işçi çalıştırılmasının İş K.'ndaki aynı esaslara bağlanmasının hayatın gerçekleri ile bağdaşmadığı, Deniz İş K. kapsamındaki çalışmaların oldukça ağır olduğu, burada en azından daha düşük bir oranın belirlenmesinin isabetli olacağı yönünde, Uşan (n 33) 212.

44 RG 20.6.1952/8140.

45 Kadir Arıcı, 'Türk Hukukunda Sakat ve Eski Hükümlü Çalıştırma Zorunluluğu ve Uygulaması' (1982) 73(1) Adalet Dergisi 84, 86-87.

46 Nurşen Caniklioğlu, Hastallk ve Sakatlı̆̆ın Hizmet Akdine Etkisi (Beta 2002) 43; Ömer Ekmekçi, ‘Özürlü, Eski Hükümlü ve Terör Mağduru İstihdamında Yaşanan Sorunlar ve İtiraz Usulündeki Değişiklikler' (2005) 19(5) Çimento İșveren (Yașanan Sorunlar) 42,47; Alpagut, Özürlü Çalıştırma (n 41) 123; Fatma Burcu Savaş, 'Çalışma Yaşamında Engelli Bireyin İstihdam Sorunları ve Yasal Yükümlülükler’ (2014) 2 Prof. Dr. Feridun Yenisey’e Armağan (Beta 2014) 2615,2617.

47 Caniklioğlu (n 46) 48.
} 
Kanımca da, baskın görüşe katılmak gerekir. Ancak olması gereken hukuk açısından, basın işyerlerinde de engellilerin istihdam edilmesinin gerektiği açıktır.

\section{2. İşyerinde Elli veya Daha Fazla İşçi Çalıştırılması}

Engelli işçi çalıştırma zorunluluğunun doğması için, işyerinin yalnızca İş Kanunu ve Deniz İş Kanunu kapsamına giren bir işyeri olması yetmemekte, aynı zamanda bu işyerinde elli veya daha fazla işçi çalıştırılması gerekmektedir. İş Kanunu'nun kapsama ilişkin 4. maddesi gereğince, tarım ve orman işlerinin yapıldığ işyerlerinde ise yükümlülüğün doğması için gereken işçi sayısı, elli bir olarak kabul edilmelidir. Çalışacak işçi sayısını tespit ederken, İş Kanunu'nda sınırları belirlenen (madde 2) işyeri kavramı gereğince; asıl işyeri yanında, bağlı işyerleri, eklentiler ve araçlardan oluşan iş organizasyonu kapsamındaki tüm birimler dikkate alınmalıdır. Ancak Kanun, aynı il sınırları içinde birden fazla işyeri bulunan işverenin bu kapsamda çalıştırmakla yükümlü olduğu işçi sayısının, toplam işçi sayısına göre hesaplanacağını da ayrıca düzenlemiştir. Böylece, işverenin birbirinden bağımsız işyerleri aynı il sınırları içinde bulunuyorsa, bu işyerlerinde çalışan işçi sayısı toplanacaktır. Görüldüğü gibi kanun, aynı işkolu, yakın mesafe vb. gibi bir ölçüt getirmek yerine; sayının toplanması bakımından coğrafi bir sınır (aynı il) kabul etmiştir ${ }^{48}$. Toplam sayının hesabında dikkate alınan bu işyerlerinin İş Kanunu veya Deniz İş Kanunu'nun kapsamına giren işyeri olması gerekir ${ }^{49}$. Kanun, çalıştırılması gereken engelli veya engellilerin birden fazla işyerinden hangisinde çalıştırılacağına yönelik bir düzenleme getirmediğinden, işveren bu işçileri ayrı ayrı her bir işyerinde ya da tek bir işyerinde çalıştırabilir ${ }^{50}$.

Konu hakkında Yargıtay kararı oldukça sınırlı olmakla birlikte, bir karara konu olan olayda, işverene yükümlülüğe uymadığı gerekçesiyle idari para cezası uygulanmış ancak işveren; sekiz adet işyeri bulunduğunu, bunların şube niteliğinde olmadığını, her birinin ayrı sektörde faaliyet gösterdiğini, kendisine engelli işçi eksiğinin tamamlanması için herhangi bir liste tebliğ olmadığını, ihtar yapılmış olsa bile eksik kontenjanın kapatılacağını belirttiğini ifade ederek cezaya itiraz etmiştir. Yargıtay 9. Ceza Dairesi, işverene, sadece engelli işçi çalıştırılmadığını tespit eden müfettiş raporuna dayanarak ceza verilmesini bir bozma sebebi olarak değerlendirmiştir ${ }^{51}$. Kanımca da karar isabetlidir. Her ne kadar, işverenin işyerlerinin şube niteliğinde olmaması ya da bağımsız bir işyeri olması, bu işyerlerinin aynı il sınırları içinde olması halinde yükümlülüğü ortadan kaldırmayacaksa da, bu konuda bir inceleme yapılmaksızın karar verilmesi yerinde değildir. Zira bu işyerlerinin bağımsız işyeri olarak farklı il sınırları içinde bulunması halinde, işverenin engelli işçi çalıştırma yükümlülüğü aynı il sınırlarındaki işyerinde çalışan işçi sayısına göre belirlenecek,

\footnotetext{
Ekmekçi, Sakat İşçi Çalıştırma (n 4) 314; Uşan, (n 33) 217.

9 Uşan (n 33) 218.

so Ekmekçi, Sakat İşçi Çalıştırma (n 4) 315.

${ }^{51}$ Yargitay 9 CD, 5352/7240, 26.12.2006 <https://www.kazanci.com> Erişim Tarihi 6.9.2019.
} 
buna göre yükümlülük ya tamamen ortadan kalkacak ya da çalıştırmakla yükümlü olunan işçi sayısı azalacaktır.

Bir işyerinde yalnızca iş sözleşmesiyle çalışanlar değil, stajyerler, çıraklar, mesleki eğitim görenler, aile hukukundan doğan yardım yükümünü yerine getirenler bulunabileceği gibi işverene karşı iş görme borcunu vekalet ya da istisna sözleşmesine dayanarak yerine getirenler de olabilir. Kanun açıkça "işçi sayısından" bahsettiği için, yukarıda anılan bu kimseler sayıya dahil edilmez. İşyerinde işçi olarak çalışanların ise, sözleşmesinin belirli ya da belirsiz süreli iş sözleşmesi olması önemli değildir (madde 30/2 ve Yönetmelik madde 11/1). Bunun gibi, diğer atipik çalışma biçimlerine göre çalışan işçilerin de sayıya dahil edilmesi gerekir ${ }^{52}$. Kısmi süreli iş sözleşmesine göre çalışanların çalışma süreleri dikkate alınarak tam süreli çalışmaya dönüştürülür ve elde edilen tam sayı işyerinde tam süreli çalışan işçi sayısına eklenir (madde 30/2 ve Yönetmelik m.11/1). Örneğin; haftada 22.5 saat çalışan bir işçi, sayının hesabına 0.5 olarak dahil edilecek ${ }^{53}$ veya haftada 15 saat çalışan üç işçi, bir işçi sayılarak işyerindeki işçi sayısına eklenecektir. Sayının hesabında, işçinin o sırada çalışıp çalışmadığı da önemli değildir. Örneğin hastalık veya yıllık izin sebebiyle işe gelmeyenler de hesaba dahil edilecektir ${ }^{54}$.

Alt işveren ilişkisinin varlığı halinde alt işverene bağlı olarak çalışanların, sayının hesabına dahil olmayacağı kabul edilmelidir ${ }^{55}$. Gerçekten, kanuna uygun bir asıl işveren alt işveren ilişkisinde, alt işveren işçilerinin asıl işverenin işçisi olduğundan söz edilemeyeceğinden bu işçiler asıl işverenin işyerine değil, alt işverenin işyerine ilişkin sayıya dahil olacaktır. Ancak, muvazaalı bir asıl işveren alt işveren ilişkisinde işçilerin başlangıçtan itibaren asıl işverenin işçisi sayılması karşısında konuya nasıl yaklaşılacağı üzerinde durulmalıdır. Kanımca, İş Kanunu madde 3'e göre muvazaa ilişkisinin itiraz edilmeyen müfettiş raporları veya mahkeme tarafindan tespit edilip alt işveren işyerinin tescil işleminin iptal edilmesinden sonra, asıl işverenin engelli işçi çalıştırma yükümü yeni sayıya göre belirlenecektir. Ancak, işçilerin "başlangıçtan itibaren" asıl işverenin işçisi olarak işlem görmesi nedeniyle, asıl işverenin engelli işçi çalıştırma yükümlülügüünün de başlangıçtan itibaren yeni sayıya göre belirlenmesi isabetli olmayacaktır. Öğretide de ifade edildiği üzere, işçilerin başlangıçtan itibaren asıl işverenin işçisi sayılması, işçinin "asıll işveren işçisi olarak çalışsa idi elde edeceği hakların ortadan kaldırılmasının engellenmesi” amacını taşır. Yani bu kural "sadece ücret ve diğer haklar ile sendikal düzen gibi, doğrudan işçinin haklarını etkileyen hususlar bakımından" hükümlerini doğurur ${ }^{56}$. Bu nedenle geriye

55 Sarper Süzek, İș Hukuku (18th edition, Beta 2019) 310; Nuri Çelik, Nurșen Caniklioğlu and Talat Canbolat, $\dot{I}_{S}$ Hukuku Dersleri (31st edition, Beta 2018) 264; Ekmekçi, Yaşanan Sorunlar (n 46) 44, Alpagut, Özürlü Çalıştırma (n 41) 121; Caniklioğlu (n 46) 55; Subaşı (n 14) 496; Savaş (n 46) 2620.

56 Ekmekçi, Yaşanan Sorunlar (n 46) 45.
} 
dönerek, işverenin engelli işçi çalıştırma yükümünü eksik yerine getirdiği veya hiç yerine getirmediği gerekçesiyle bir cezai yaptırım uygulamak mümkün değildir.

Özel istihdam büroları aracıllğıyla olsun ya da olmasın hukuka uygun bir geçici iş ilişkisiyle (madde 7) çalışan işçilerin, geçici olarak iş gördükleri işverenin işçisi olmadığı kabul edildiğinden, bu işçiler de elli işçinin hesabında dikkate alınmayacaktır ${ }^{57}$. Bununla birlikte, İş Kanunu'nun 7. maddesinde, 2016 yılında özel istihdam büroları aracılığıyla işçi çalıştırmanın yasal bir zemine kavuşturulduğu 6715 sayı11 Kanun'la ${ }^{58}$ yapılan değişiklikte, "Geçici işçi sağlama sözleşmesi ile çalışan işçi, 30 uncu maddenin uygulanmasında özel istihdam bürosu ve geçici iş̧̧i çalışırın işverenin iş̧̧̧ sayısına dâhil edilmez." kuralı kabul edilmiştir. Böylece, geçici işçi çalıştıran işveren bir kenara bırakılırsa, özel istihdam bürosu işyerlerinde toplam işçi sayısı hesaplanırken, geçici işçi sağlama sözleşmesiyle çalışanlar dikkate alınmayacaktır.

Engelli işçi çalıştırma yönünden özel istihdam büroları ve geçici işçi çalıştıran işveren adına bu yönde bir istisna tanıyan 6715 sayılı Kanun; bu işverenlere bir imtiyaz tanındığ 1 ve devletin engellileri koruma yükümlülüğünün ortadan kaldırdığı gerekçesiyle, Anayasa Mahkemesi'ne götürülmüştür. Yüksek Mahkeme ilk olarak, geçici işveren bakımından sayıya dahil edilmeme kuralının "geçici iş̧̧inin geçici işverenin işyerinde geçici olarak çallşması ve geçici iş̧̧i ile geçici işveren arasında bir iş sözleşmesinin bulunmamasının bir sonucu" olduğunu açıklamıştır. Mahkeme, geçici işçinin özel istihdam bürosunun işçisi olduğunu belirttikten sonra "özel istihdam bürosu geçici işçiyi kendi işyerinde çallştırmamakta ve geçici işverenin işyerinde çalışmak üzere görevlendirmektedir. Dolayısıyla geçici işşinin, özel istihdam bürosunun Kanun'un 30. maddesinde öngörülen engelli çalıştırma yükümlülüğ̈̈nün belirlenmesindeki işçi sayısına dâhil edilmemesi de geçici iş̧̧inin özel istihdam bürosuna ait bir işyerinde çalışmamasından kaynaklanmaktadır." biçimindeki bir açıklamayla Anayasa'ya aykırılık iddiasını reddetmiştir ${ }^{59}$. Kanımca da bu sonuç, özel istihdam bürosu aracıllğıyla geçici iş̧̧i çalıştırma ilişkisinin niteliğinden kaynaklanmaktadır. Belirtmek gerekir ki, tıpkı geçici işveren gibi, özel istihdam bürosunun kendi işyerinde çalıştırdığ 1 işçilerin sayısı elli veya daha fazla ise, büronun da engelli işçi çalıştırma yükümü altında olduğu açıktır. Hesapta dikkate alınmayan işçiler, geçici işçi sağlama sözleşmesiyle başka işverenlere gönderilen işçilerdir.

Sayının hesabında dikkate alınmayacak işçi gruplarından bir diğeri, yer ve su altında çalışan işçilerdir. Zira 30. maddenin 4. fikrasında açıkça "Yer altı ve su altı işlerinde engelli iş̧̧ çalıştırılamaz ve yukarıdaki hükümler uyarınca işyerlerindeki

Süzek (n 55) 323; Çelik, Caniklioğlu, Canbolat, (n 55) 264; Alpagut, Özürlü Çalıştırma (n 41 ) 121.

58 RG 20.5.2016/29717.

59 Anayasa Mahkemesi, 141/27, 28.2.2018, RG 29.3.2018/30375. 
işçi sayısının tespitinde yer altı ve su altı işlerinde çalışanlar hesaba katılmaz." Yer ve su altında engelli işçilerin çalışmasının zorluğu karşısında bu hükmün yerinde olduğu kuşkusuzdur ancak, yer ve su altı işi olmamakla birlikte ağır ve tehlikeli olan birçok işte de engelli iş̧̧i çalıştırmak oldukça güçtür. Bu nedenle bu işler bakımından da sayının hesabında bir istisna getirilmesi ya da oranının düşürülmesi isabetli olabilir ${ }^{60}$. Ayrıca, 5188 sayılı Özel Güvenlik Hizmetlerine Dair Kanun' 'a ${ }^{61}$ dayanılarak çıkarılan uygulama yönetmeliğinde, özel güvenlik birimlerinde ve özel güvenlik şirketlerinde çalıştırılacak engelli sayısının tespitinde, özel güvenlik görevlilerinin hesaba dahil edilmeyeceği düzenlenmiştir (madde 47 ve Yurt İçinde İşe Yerleştirme Yönetmeliği madde 11/3). O halde, özel güvenlik şirketleri yanında kurumların kendi güvenlik ihtiyacını karşılamak için oluşturduğu güvenlik biriminde güvenlik elemanı olarak çalışanlar sayıya eklenmeyecektir.

Son olarak, işyerinde hâlen çalıştırılan engelli, eski hükümlü ve terörle mücadelede malul sayılmayacak şekilde yaralanan işçiler, toplam iş̧̧i sayısının hesabında dikkate alınmaz (Yönetmelik madde 11/6). Buna göre tam süreli bir iş sözleşmesiyle çalışan engelli, eski hükümlü veya terör mağduru, işyerinde toplam işçi sayısından düşülecektir. Bu durumda işyerinde halihazırda kısmi süreli iş sözleşmesi ile çalışan engellilerin sayının hesabından nasıl hariç tutulacağı sorusu akla gelebilir. Bu durumda tıpkı sayının hesabında olduğu gibi, kısmi süreli çalışan engellilerin çalışma süreleri dikkate alınarak tam süreli çalışmaya dönüştürülecek ve elde edilen bu tam sayı toplam işçi sayısından eksiltilecektir (Yönetmelik madde 11/1).

\section{Yükümlülük Kapsamında Çalıştırılacak Engelliler}

İşverenin 30. maddedeki istihdam yükümünü yerine getirmesi için, çalıştıracağ1 kimsenin engelli olması gerekir. Bununla birlikte İş Kanunu madde 30'da, istihdam edilecek engelliye ilişkin bir tanım yapılmamıştır. Engelli kavramına yönelik çok sayıda tanım yapılmakla birlikte, Dünya Sağlık Örgütü’ne göre engellilik, "kişiden veya bir bütün olarak vücuttan beklenilen davranışlar, beceriler ve görevler olarak ifade edilen normal aktivitelerin gerçekleştirilmesindeki eksiklik veya sinırlılıktır ${ }^{62}$ ". Hukukumuzda ise 5378 sayılı Engelliler Hakkında Kanun, "Fiziksel, zihinsel, ruhsal ve duyusal yetilerinde çeşitli düzeyde kayıplarından dolayı topluma diğer bireyler ile birlikte eşit koşullarda tam ve etkin katılımını kisıtlayan tutum ve çevre koşullarından etkilenen bireyi" engelli olarak tanımlamaktadır (madde 3/1,c).

Konumuz bakımından önemli olan, bir diğer ifadeyle işyerinde istihdam edilecek engelliye ilişkin tanım, Yurt İçinde İşe Yerleştirme Hizmetleri Yönetmeliği’nde

\footnotetext{
60 Kota oranlarının tespitinde işkolu veya sektör bazında özelliklerin dikkate alınması yönünde, Alpagut, Özürlü Çalıştırma (n 41) 123.

${ }^{61}$ RG 26.6.2004/25504.

62 WHO, International Classification of Impairments Disabilities and Handicaps (1976) 30.
} 
yapılmıştır. Buna göre engelli; "Doğuştan ya da sonradan herhangi bir nedenle bedensel, zihinsel, ruhsal, duyusal ve sosyal yeteneklerini çeşitli derecelerde kaybetmesi nedeniyle toplumsal yaşama uyum sağlama ve günlük gereksinimlerini karşılamada güçlükleri olan ve korunma, bakım, rehabilitasyon, danışmanlık ve destek hizmetlerine ihtiyaç duyan kişilerden tüm vücut fonksiyon kaybının en az yüzde kırk olduğu sağlık kurulu raporu ile belgelenenleri" ifade eder (madde 3/1,e). Görüldüğü üzere, engelliliğin doğuştan ya da sonradan gerçekleşmesi, gerçekleşme nedeni, engellinin yaşı gibi belirlemelere maddede yer verilmiş değildir. Ancak engellinin, iş arayan olarak Türkiye İş Kurumu'na ${ }^{63}$ kaydolması için on dört yaşını doldurması gerekir (madde 15). Bunun gibi, aşağıda korumalı işyerleri konusunda anlatılanın aksine; engellilik bakımından, bedensel, zihinsel ya da ruhsal engellilik konusunda bir ayrım yapılmamıştır. Yönetmelikte, engelliliğin oranı olarak, tüm vücut fonksiyonlarında en az yüzde kırk kayıp oranı kabul edilmiştir. Engellilerin iş arayan olarak Kuruma kaydolması ve Kurum hizmetlerinden yararlanması, bu oranı bir sağlık kurulu raporuyla ${ }^{64}$ belgelemesine bağlıdır. Ancak, sağlık raporunda "çalışamaz" durumda olduğu belirlenen engellilerin Kuruma tescilinin yapılması mümkün değildir.

Tüm bu açıklamalar 1şı̆̆ında, İş Kanunu m.30 kapsamında istihdam yükümlülüğünden yararlanacak olan engelliler; 14 yaşını doldurmuş, en az yüzde 40 oranında engelli olduğunu sağlık kurulu raporuyla belgelendiren bireylerdir. Öte yandan, engellinin iş arayan olarak Kuruma kaydolması ya da Kurum aracılığı olmadan çalıştırılıyorsa sonradan Kurum tarafından tescilinin yapılması da zorunludur. Zira Kurum tarafından tescili yapılmayanların engelli statüsünde değerlendirilmeyeceği, Yönetmelikte açıkça belirtilmiştir (madde 13/2).

\section{Yükümlülüğe İlişkin Diğer Esaslar}

Engelli işçi çalıştırmaya ilişkin ilk iki koşul, hükmün kapsamına giren bir işyerinin bulunması ve çalıştırılacak kişinin Yönetmelik gereğince engelli olarak kabul edilen kimselerden olmasıdır. Ancak, bu şartların yanında Yönetmelikte belirtilen, daha çok usule ilişkin birtakım şartlar da bulunmaktadır.

\section{Engellinin Kurum Aracılığı ile Sağlanması ve İstinası}

$\mathrm{Bu}$ şartlardan ilki, işçilerin Kurum aracılığıyla sağlanmasıdır. 30. maddede, işverenlerin çalıştırmakla yükümlü oldukları işçileri Kurum aracılığıyla sağlayacakları

\footnotetext{
Çalışmanın devamında Kurum olarak adlandırılacaktır.

${ }_{64}$ Sağlık raporunun engellinin istihdam edilebileceği uygun işlerin tespiti yönünden gerekli olduğu, geçmiş yıllarda sağlık kuruluşlarının engellilerin istihdam edilebilirliği konusunda genellikle yetkin olmamaları engellinin istihdamına engel olabildiği, güncel uygulamalarda uzman sağlık kuruluşunun belirlenmesinin ve rapor içeriğinin değiştirilmesinin isabetli olduğu yönünde, E. Murat Engin, 'Çalışma Yaşamında Özürlülük' (2009) (2) Galatasaray Üniversitesi Hukuk Fakültesi Dergisi 13,15 .
} 
kuralı getirilmiş, Yönetmelikte de aynı esas tekrar edilmiştir (madde 13). Ancak bu kural, kesin ve mutlak bir kural değildir. Yönetmelikte, özel sektör işverenlerinin Kurum aracilığı olmadan engelli istihdam edebilmesine imkân verilmiş ancak işe başlama tarihinden itibaren bu durumun en geç on beş iş günü içinde Kuruma bildirilmesi ve tescil ettirilmesi zorunluluğu getirilmiştir (madde 13/2). Bu istisnanın ${ }^{65}$, istihdamı kolaylaştırıc1 etkisinin olduğunu, sözleşme yapma serbestisi çerçevesinde ve işverene kendi iş̧̧isini seçme hakkının tanınması karşısında yerinde olduğunu söylemek gerekir. Yine işverenin, Kurum aracıllğı olmaksızın işyerinin işçisi iken engelli duruma düşenlere öncelik tanıyarak bu işçiyi yükümlülük kapsamında çalıştırılan engelli işçi olarak istihdam etmesi mümkündür. Bu durumda da işçinin Kurum tarafından tescilinin yapılması istenilmeli ve gerekli belgeler sunulmalıdır (madde 16).

Yükümlülük kapsamındaki işverenin, çalıştırmakla yükümlü bulunduğu işçiyi Kurumdan talep ederken, bu işçilere ilişkin nitelikleri de belirtmesi gerekir. Talebinde nitelik belirtmeyen işverenin, sonradan gönderilen kişilerin uygun olmadığ yolunda bir itirazda bulunamayacağ ${ }_{1}$ da öğretide ifade edilmiştir ${ }^{66}$. Kuşkusuz; işverenin belirttiği niteliklerin, yükümlülükten kaçmak ya da bunu geciktirmek amacı taşımayan, dürüstlük kuralına uygun, kabul edilebilir nitelikler olması gerekir. Ayrıca işverenin, i) işin gerektirdiği ağırlıklı vasıfların üstünde istihdamı zorlaştırıcı şartlar öne sürmesi, ii) işin niteliği gerektirmediği sürece engellilik oranına üst sınır getirmesi, iii) engel grupları arasında (bedensel, zihinsel engelli gibi) bir ayrım yapması yasaktır. Yönetmelikte yer verilen bu yasaklar, istihdam yükümünden kurtulmanın önüne geçmesi açısından anlamlıdır. Ancak, işin gerektirdiği ağırlıklı vasıfların ne olduğu veya işin niteliğinin hangi oranda ve hangi engel grubunda bir işçinin çalışmasına imkân verdiğini tespit etmek her zaman kolay değildir. Belirtmek gerekir ki, işverenin bildirdiği nitelikler, gerçekten işin gerektirdiği türden nitelikler ise Kurum kayıtlarında bu nitelikte işçinin olmaması; bu niteliklerin, istihdamı zorlaştırıcı özellikte olduğu anlamına gelmez ve giderek, işverenin yükümlülüğünü yerine getirmediği gerekçesiyle bir yaptırım uygulanması gerekmez.

\section{Süre Şartı}

$\mathrm{Bu}$ yükümlülüğün yerine getirilmesi bir süre şartına da bağlanmıştır. Talep süresi olarak isimlendirebileceğimiz ilk sürede, işverenin yükümlülüğün doğmasından itibaren beş iş günü içinde, çalıştırmakla yükümlü olduğu işçileri Kurumdan talep

\footnotetext{
5 İstisnanın yalnızca özel sektör işverenine tanınmasının gerekçesi ise, kamu işverenlerinin işçi alımlarının, kamu işçi istihdamına ilişkin mevzuat hükümlerine göre yapılmasıdır. Bu kapsamda, engelli işçilerin alınmasına yönelik detaylar Kamu Kurum Ve Kuruluşlarına İşçi Alınmasında Uygulanacak Usul ve Esaslar Hakkında Yönetmelik’te yer almaktadır. $\mathrm{Bu}$ yönetmelikte engelli tanımı, Engelliler Hakkında Kanun ve İșe Yerleștirme Hizmetleri Yönetmeliğine benzer șekilde yapılmış (m.3/1,1) ve engellilerin kamu işyerlerinde istihdamı için Engelli Kamu Personeli Seçme Sınavı (EKPSS) puanı aranmıştır (m.10)

66 Ekmekçi, Yaşanan Sorunlar (n 46) 46.
} 
etmesi gerekir (Yönetmelik madde 14/1). Bu süre kamu ve özel sektör işverenleri bakımından aynıdır. Buna göre, işyerinin engelli çalıştırma yükümlülüğünün kapsamına girmesi (başka bir işyerinin devralınması, işçi istihdamı sonucu sayının artması, yükümlülük kapsamında çalışan engelli işçinin iş sözleşmesinin sona ermesi gibi) üzerine, beş iş günü içinde işverenin Kuruma başvuru yapması gerekir. Önceki yönetmelikte yedi gün olan bu sürenin kısa olduğu ve işverenin kısa sürede bu kişileri istihdam edeceği iş alanlarını ve işçilerin niteliklerini belirlemesinin beklenemeyeceği ifade edilmiştir ${ }^{67}$. Kanımca, aynı çelişki beş iş günlük süre için de geçerlidir ve beş iş günlük süreyi yeterli bulmak mümkün değildir. Sürenin kısa olması, işverenin engelli işçinin niteliklerini gereği gibi belirleyememesi sonucu adaylarla olan görüşmenin uzamasına yani istihdamı hızlandırmak yerine geciktirmesine, engelli işçinin çalışacağı iş alanın iyi tespit edilmeyerek çalışma koşullarında engelli aleyhine bir durum oluşmasına yol açabilir.

Yükümlülüğün karşılanma süresi olarak tanımlanabilecek süre sınırı yalnızca özel sektör işverenleri açısından getirilmiştir. Buna göre, adayların Kurum tarafından özel sektör işvereniyle görüştürülmesinden sonra, işverenin görüşmeden itibaren on beş gün içinde engelli açığını karşılaması gerekir. Böylece adaylarla olan görüşmelerin neticelendirilmesinin gereksiz yere uzatılması engellenmeye çalışılmışıtır. On beş günlük sürenin, bir işverenin çalışmaya başlayacağı işçiyi seçmesi için yeterli bir süre olup olmadığı tartışılabilir. Kanımca bu süre gereksiz uzatmaların önüne geçmesi açısından makul bir süredir. Ancak yukarıda yer verildiği gibi, talep süresinin kısa tutulması, iş alanlarını ve ihtiyaçlarını yeterince belirleyemeyen işvereni görüşmelerden sonra karar vermek bakımından zor durumda bırakabilir. Yönetmelikte, özel sektör işvereni bakımından engelli açığının, yükümlülüğün doğduğu tarihten itibaren otuz gün içinde karşılanması zorunlu tutulmuştur (madde 15). Şu halde, talep süresi ve görüşme süresi de dahil olmak üzere ihtiyacın doğduğu andan itibaren otuz gün içinde engelli işçinin istihdam edilmesi gerekir. İşverenler açısından otuz günlük süre uyulması gereken zorunlu bir süre olsa da, Kurum tarafından işin niteliklerine uygun engellinin sağlanamaması halinde işverene bir yaptırım uygulanması mümkün değildir. On beş gün ve otuz günlük süre özel sektör işverenleri için zorunlu olup, yukarıda yer verildiği üzere kamu işverenleri için özel mevzuat gereğince, bu süreler uygulanmaz.

\section{Kurumun Engellileri İşverenle Görüştürmesi ve Engellinin İşe Alınması}

Belirli sürede Kuruma başvurmak ve istihdam yükümlülügünü yerine getirmenin işverenlerin borcu olması karşısında, nitelikleri uygun engellileri işverenle görüş̧ürmek de Kurumun görevidir. Yönetmelik’te, “Kurum, özel sektör işvereninin engelli talep tarihinden itibaren en geç on gün içinde, başvuranlardan nitelikleri 
uygun engellileri durumlarını ve niteliklerini belirten belgelerle birlikte işverenle görüştürür" kuralı getirilerek (madde 15/2), Kurumun bu görevini yerine getirmesi bir süreye de bağlanmıştır. Kanımca, süresine uygun bir şekilde engelli çalıştırma talebinde bulunan ișverenin engelli talep tarihinin üzerinden, on günden uzun bir sürenin geçmesi ve bu nedenle yükümlülüğün doğduğu tarihten itibaren otuz gün içinde istihdamın sağlanamaması halinde, gecikilen süre için işverene bir cezai yaptırımın uygulanmaması, uygulanmışsa iptal edilmesi gerekir.

Kurumun işverenin başlangıçta işçi talep ederken belirttiği niteliklere ve iş alanlarına uygun engellileri işverenle görüştürmesi gerekir. Bununla birlikte hükmün devamında, işverenin bu görüşmeden itibaren engelli açığını, en geç on beş gün içinde, Kurum tarafından görüştürülenler ya da Kurum portalında kayıtlı diğer engelli iş arayanları bizzat seçerek veya kendi imkânlarıyla temin ettiği engelliler arasından karşılayacağı belirtilmiştir. Aynı zamanda işveren, işe alınanları ve alınmayanları, alınmayış nedenlerini de belirterek Kuruma bildirmelidir. Şu halde işverene istihdamı gerçekleştirmek için üç ayrı imkân (görüştürülenlerden seçme, portaldan seçme, kendi imkânlarıyla temin etme) tanınmıştır. Bu noktada, işverenin, Kurum tarafindan aranan nitelikte engelli gönderilmemesi halinde diğer iki imkânı da kullanarak, belirlenen süre içinde muhakkak bir işe alım yapmasının zorunlu olup olmadığı sorusu akla gelir. Kanımca, gerek emredici nitelikteki otuz günlük süre sınırı gerekse 15. maddedeki ifade, Kurum tarafından, belirtilen nitelikte işçi gönderilmese veya görüşmelerden bir sonuç alınmasa bile, işverenin bu istihdamı gerçekleştirmekle zorunlu olduğu sonucunu doğurur. Ancak işverenin, kimi özel durumlarda işin gerektirdiği ve dürüstlük kuralına uygun olarak belirlediği niteliklerde bir işçinin Kurum portalında bulunmadığını, bu konuda gerekli görüşmeleri ve yazışmaları yaptığını ve kendi imkânları ile belirleyemediğini ispatlaması halinde ceza yaptırımının uygulanmaması yerinde olacaktır.

Belirtmek gerekir ki, işveren engelli işçi çalıştırma yükümünün ortaya çıkmasıyla birlikte, iş seçiminden, başvuru formlarının değerlendirilmesi, hangi engellinin çalıştırılacağının seçim süreci, teknik değerlendirme, önerilen çalışma süreleri ve şartlarına kadar olan aşamaların hiçbirinde, ayrımcı bir muamelede bulunamaz. Bu durumun, bir kimsenin engelliliğinden kaynaklanan nefret nedeniyle işe alınmasının engellenmesi biçiminde gerçekleşmesi halinde; failin Türk Ceza Kanunu madde 122 gereğince, nefret ve ayrımcılık suçu nedeniyle cezalandırılması gerekir. Yönetmelik’te ayrıca, çalışan engellilerin aleyhine de ayrımcı bir muamelenin yasak olduğu ifade edilmiştir (madde 17/2). Anayasa madde 10, İş Kanunu madde 5 'te yer alan eşit davranma borcu ve ayrımcılık yasağ ile $^{68}$ kişilerin eşit muamele görme hakkının güvence altına alınarak hak ve hürriyetlerden yararlanmada ayrımcılığın

68 Ayrıntılı açıklamalar için bkz Gaye Burcu Yıldız 'Türk İş Hukukunda Özürlülük ve Sağlık Durumuna Dayalı Ayrımcılık Yasă̆ı' (2008) (10) Sicil İş Hukuku Dergisi 80,81 ff; Engin (n 64) 24; Savaş (n 46) 2625-2629. 
önlenmesi amacıyla yürürlüğe giren 6701 sayılı Türkiye İnsan Hakları ve Eşitlik Kurumu Kanunu'nda ${ }^{69}$ düzenlenen kurallar karşısında, Yönetmelik'te böyle bir hüküm yer almasa bile aynı sonuca ulaşmak mümkündür. İş ilişkisi sırasında, çalışan engellilere yönelik engellerinden dolayı bir ayrım yapılması durumunda, İş Kanunu madde 5 uyarınca işçinin, dört aya kadar ücreti tutarındaki uygun bir tazminattan başka yoksun bırakıldı̆̆ haklarını da talep edebilmesi söz konusu olacaktır. Ayrıca; Eşitlik Kanunu'nda fiziksel, zihinsel, ruhsal ve duyusal yetilerinde çeşitli düzeyde kayıplarından dolayı topluma diğer bireyler ile birlikte eşit şartlarda tam ve etkin katılımını kısıtlayan tutum ve çevre şartlarından etkilenen birey olarak tanımlanan (madde 2/1,f) engellilere yönelik, engellilik temellerine dayalı ayrımcılığın yapılmas1 açıkça yasaklanmış ve bu yasağın ihlali halinde; konuya ilişkin görev ve yetkisi bulunan kamu kurum ve kuruluşları ile kamu kurumu niteliğindeki meslek kuruluşları, ihlalin sona erdirilmesi, sonuçlarının giderilmesi, tekrarlanmasının önlenmesi, adli ve idari yoldan takibinin sağlanması amacıyla gerekli tedbirleri almakla yükümlü kılınmıştır (madde 3). Aynı zamanda bu Kanunun, İstihdam ve serbest meslek başlıklı 6. maddesinde; işverenlerin, kişiler hakkında bilgilenme, başvuru, seçim kriterleri, işe alım şartları ile çalışma ve çalışmanın sona ermesi süreçleri dâhil olmak üzere, işle ilgili süreçlerin hiçbirinde ayrımcılık yapamayacağı düzenlenmiştir.

\section{E. Yükümlülüğün Gerçekleştirilmesine Yönelik Teşvik}

İşverenin engelli işçi çalıştırmasının teşviki adına, 30. maddenin 6. fikrasında özel bir teşvik hükmü getirilmiştir. Bu teşvik, engelli iş̧̧ilerin sigorta primlerinin bir kısmının Hazine tarafından ödenmesine yöneliktir. Buna göre, özel sektör işverenlerince bu madde kapsamında çalıştırılan engelli sigortalıların, belirlenen prime esas kazanç alt sınırı üzerinden hesaplanan sigorta primine ait işveren hisselerinin tamamı, Hazine tarafından ödenecektir. Ayrıca kontenjan fazlası ve yükümlü olmadığı halde engelli çalıştıran işverenlere de aynı prim teşviki getirilmiş ve bu şekilde çalıştırılan her bir engelli için prime esas kazanç alt sınırı üzerinden hesaplanan sigorta primine ait işveren hisselerinin tamamının Hazinece karşılanacağı belirlenmiştir. Hüküm, 2014 yılında 6518 sayılı Kanun'la değiştirilmeden önce, işverenin engelli işçiyi kontenjan dahilinde çalıştırması halinde teşvik oranı tam, kontenjan fazlası ya da yükümlü olmamasına rağmen çalıştırması halinde yüzde elli olarak uygulanmaktaydı. Bugün için teşvik oranının artırılmasının yerinde olduğunu söylemek gerekir.

Hazine tarafından bu primlerin karşılanabilmesi için işverenlerin çalıştırdıkları sigortalılarla ilgili olarak, aylık prim ve hizmet belgelerini yasal süresi içerisinde Sosyal Güvenlik Kurumu'na vermeleri ve sigortalıların tamamına ait sigorta primlerinin sigortalı hissesine isabet eden tutarı ile Hazinece karşılanmayan işveren hissesine ait tutarı ödemiş olmaları gerekir. Görüldüğü gibi, bu teşvik özel sektör

$\overline{69}$ RG 20.4.2016/29690. 
işverenlerine, sigortalı engellinin prime esas kazancı ne olursa olsun alt sınır üzerinden ve işveren hissesi bakımından getirilmiştir. Engelliye prime esas kazanç alt sınırı üzerinde bir ücret ödeniyorsa, bu miktara ilişkin sigorta primlerinin işveren hissesine düşen kısmı işveren tarafindan ödenmelidir. Ancak Sosyal Güvenlik Kurumu'na gerekli belgeleri vermeyip, primleri zamanında ödemeyen işverenin bu teşvikten yararlanması mümkün değildir. Bu teşvikten yararlanmak için işverenlerin Sosyal Güvenlik Kurumu'na idari para cezası borcu bulunmaması şartı ise aranmamıştır ${ }^{70}$.

\section{Engelli Çalıştırma Yükümüne Aykırılığın Yaptırımı}

Engelli işçi çalıştırma yükümüne uyulmamasının yaptırımı İş Kanunu madde 101'de belirtilmiş̧tir. Buna göre, "Bu Kanunun 30 uncu maddesindeki hükümlere aykır olarak engelli ve eski hükümlü çalıştırmayan işveren veya işveren vekiline çalıştırmadiğı her engelli ve eski hükümlü ve çalıştırmadiğı her ay için binyediyüz Türk Lirası idari para cezası verilir. Kamu kuruluşları da bu para cezasından hiçbir şekilde muaf tutulamaz". Benzer olarak Deniz İş Kanunu'nda da "13 üncü madde gereğince engelli ve eski hükümlü gemi adamı çalıştırma ile ilgili kanun ve yönetmelik hükümlerine uymayan işveren veya işveren vekiline çallştırmadı̆̆ her engelli veya eski hükümlü ve çalıştırmadlğ her ay için ikibin Türk Lirası idarî para cezası verilir" (madde 50/ç). Yurt İçinde İşe Yerleştirme Hizmetleri Hakkında Yönetmelik’te de, engelli işçiler hakkında yapılacak denetimin, İş K.'nun çalışma hayatının denetimine ilişkin kurallara göre yapılacağı belirtildikten sonra aynı esas tekrar edilmiştir (madde 21). Görüldüğü gibi, engelli çalıştırmamanın hukuki yaptırımı her iki kanunda da bir tazminat olarak değil, idari para cezası olarak belirlenmiştir. Esasen İş K.'nda sözleşme yapma zorunlulukları kapsamında tazminat yaptırımı öngörülen iki hal, maluliyeti ortadan kalkan işyerinin eski işçileri (madde 30/5) ile askerlik veya kanundan doğan bir görevi tamamlayarak dönenlerin (madde 31/4) işe alınmaması halidir.

İdari para cezaları, kabahatler karşıllğıında öngörülen yaptırımlardan birisidir. $\mathrm{Bu}$ cezaların özelliği; idari organlar tarafından uygulanmaları ve yargı tarafindan ancak itiraz üzerine değerlendirilmeleridir ${ }^{71}$. İş hukukunda idari para cezaları, iş hukuku mevzuatında getirilen kimi kuralların hiç veya gereği gibi uygulanmaması nedeniyle öngörülen ve yaygın bir uygulama alanına sahip (İş Kanunu madde 98108, Deniz İş Kanunu madde 50-53, Basın İş Kanunu madde 26-27, Sendikalar ve Toplu İş Sözleşmesi Kanunu madde 78, İş Sağllğ 1 ve Güvenliği Kanunu madde 26, Sosyal Sigortalar ve Genel Sağlık Sigortası Kanunu madde102) kamu hukuku

\footnotetext{
70 A. Can Tuncay and Ömer Ekmekçi, Sosyal Güvenlik Hukuku Dersleri (19th edition, Beta 2017) 198; Ali Güzel, Ali Rıza Okur and Nurșen Caniklioğlu, Sosyal Güvenlik Hukuku (17th edition, Beta 2018) 306.

71 Tankut Centel, ‘Özürlü Çalıştırma Yükümüne Aykırılığa İlişkin Cezai Sorumluluk Esasları' (2010) (20) Sicil İş Hukuku Dergisi, 5,5.
} 
yaptırımlarıdır. $\mathrm{Bu}$ yaptırıma ilişkin temel esaslar Kabahatler Kanunu'nda ${ }^{72}$ düzenlenmiştir. Kabahatler Kanunu'nun 3. maddesi gereğince, bu kanunun genel hükümleri diğer kanunlarda düzenlenen idari para cezalarına da uygulanacağından, engelli çalıştırma yükümlülüğüne aykırılık halinde de Kabahatler Kanunu'nun genel hükümleri amirdir.

İdaripara cezalarınınuygulanmasının sebebibirkabahat(idarisuç)oluşturduğundan, bu suçun unsurlarının gerçekleşmesi gerekir. Engelli işçi çalıştırmama kabahatinin maddi unsuru, hiç veya gereken sayıda engelli işçi çalıştırılmamış olmasıdır ${ }^{73}$. Öte yandan suçun manevi unsurunun (kusurun) da oluşması gerekir. Engelli işçi çalıştırmamanın taksirle işlenmesi mümkün olmadığından, bu kabahat için kasıtlı hareket gerekir. $\mathrm{Bu}$ nedenle, yukarıda açıklandığı gibi, işverenin, engelli işçi çalıştırma iradesini gösterip gerekli işlemleri yapması halinde, idari suçu işleme kastının varlığından bahsedilmemelidir ${ }^{74}$. Ancak uygulamada, yasal süreyi geçiren işverenlerin doğrudan idari para cezasına çarptırıldığı ve buna ilişkin itirazların gereğince değerlendirilmediği bilinmektedir.

Söz konusu idari para cezas1, İş Kanunu madde 108'deki özel hüküm gereğince, doğrudan Türkiye İş Kurumu İl Müdürü tarafından verilecek ve genel esaslara göre tahsil edilecektir. 101. maddede belirlenen idari para cezası, çalıştırılmayan her engelli ve çalıştırılmayan her ay için belirlendiğinden maktu değil, önceden belli olmayan nisbi nitelikte bir cezadır. Bu idari para cezası, yeniden değerleme oranı ${ }^{75}$ sonucunda, 2019 yılı için 3.250 Türk Lirası olmuştur. Bu miktar, çalıştırılmayan her engelli ve çalıştırılmayan her ay için hesaplanır. Öte yandan, bu yükümlülüğe uyulmaması nedeniyle tahsil edilen cezalar, "engellilerin kendi işini kurmaları, iş bulmasını sağlayacak destek teknolojileri, engellinin işe yerleştirilmesi, işe ve işyerine uyumunun sağlanması ve bu gibi projelerde" kullanılacaktır (madde 30/7).

Maddede, kamu kuruluşlarının para cezasından hiçbir şekilde muaf olmayacakları da ayrıca belirtilmiştir. Esasen bu yönde bir hüküm olmasa bile, yaptırım tüm işverenlere getirildiğinden, işveren niteliğine sahip bu kuruluşların da engelli işçi çalıştırma yükümünde oldukları ve aykırılık halinde idari para cezası yaptırımıyla karşılaşacakları açıktır. Ancak bu düzenleme; geçmişte kamu kuruluşlarının çeşitli genelgeler yayınlayarak para cezasından sorumlu olmadıkları yönündeki uygulamalarının önüne geçmek ve tereddütleri gidermek açısından anlamlıdır ${ }^{76}$.

\footnotetext{
RG 31.3.2005/25772 mükerrer.

Centel (n 71) 8; Engin (n 64) 21.

Centel (n 71) 9.

5 Yeniden değerleme oranı, 213 sayılı Vergi Usul Kanunu'nun mükerrer m.298/B fikrasına göre, yeniden değerleme yapılacak yılın Ekim ayında (Ekim ayı dahil) bir önceki yılın aynı dönemine göre Türkiye İstatistik Kurumunun Yurt İçi Üretici Fiyat Endeksinde meydana gelen ortalama fiyat artış oranıdır. Bu oran 2019 yılı için yüzde 23.73'dür.

76 Ekmekçi, Yaşanan Sorunlar (n 46) 50.
} 
Engelli işçi çalıştırma yükümüyle ilgili olan bir diğer idari para cezası da 4904 sayılı Türkiye İş Kurumu Kanunu'nun ${ }^{77}$ 20. maddesinden doğmaktadır. Maddenin, ilk fikrasının (i) bendi gereğince, Kurum tarafından istenilen rapor, bilgi ve belgeler ile işgücü piyasasının izlenmesi için gerekli olan istatistiksel bilgileri Kurumca belirlenen süre içerisinde ibraz etmeyenlere 3.000 Türk Lirası idari para cezası verilecektir. Buna göre, işverenlerden çalıştırdıkları engelli işçi sayısına, bunların çalıştı̆̆ iş alanlarına ilişkin talep edilen bilgilerin verilmemesi bir kabahat olarak kabul edilmiştir.

Nihayet, idari para cezalarına itiraz, bu konuda İş Kanunu'nda özel bir düzenleme bulunmadığından Kabahatler Kanunu'ndaki hükümlere (madde 3 ve 27) göre yapılacaktır. Buna göre, engelli işçi çalıştırma yükümüne uymadığı gerekçesiyle Kurum il müdürü tarafından idari para cezası verilen işveren, yaptırım kararının tebliğinden itibaren on beş gün içinde sulh ceza hâkimliğine başvuracaktır ${ }^{78}$. Bu süre içinde başvuru yapılmaması halinde idari para cezası kesinleşecektir. Belirtmek gerekir ki, idari para cezalarına itirazlardan kaynaklanan uyuşmazlıklarda görevli mahkemenin neresi olduğu geçmişten günümüze yapılan mevzuat değişiklikleri nedeniyle oldukça tartışma konusu olmuştur. Bugün için 7036 sayılı İş Mahkemeleri Kanunu'nda $^{79}$ da idari para cezalarına itirazlar, iş mahkemelerinin görev alanından istisna tutulmuştur (madde 5/b). Bu nedenle, Türkiye İş Kurumu tarafından uygulanan idari para cezalarına karşı yapılan başvuru, sulh ceza hâkimliklerinde görülmeye devam edecektir ${ }^{80}$.

\section{Korumalı İşyerleri}

19. yüzyılın başlarında Amerika Birleşik Devletleri'nde uygulanmaya başlanan, "koruyucu istihdam" (sheltered employment), engelli istihdamina yönelik tek başına ya da diğer yöntemlerle birlikte uygulanabilecek bir istihdam yöntemidir. $\mathrm{Bu}$ yöntem kısaca, çalışma hayatına kazandırılmaları güç olan engellilerin, özel koşullar çerçevesinde istihdamının sağlanması olarak tanımlanabilir ${ }^{81}$. Bu sistemde, engellilerin istihdamını sağlamak amacıyla, çalışma ortamının özel olarak düzenlendiği "korumalı işyerleri”" (sheltered workplaces) bulunmaktadır ${ }^{82}$.

\footnotetext{
77 RG 5.7.2003/25159.

78 Yargıtay 9 HD, 26448/27819, 5.9.2012; Uyuşmazlık Mahkemesi, 106/136, 7.6.2010 <https://www.kazanci.com> Erişim Tarihi 6.9.2019.

79 RG 25.10.2017/30221.

80 Konu hakkında yapılan mevzuat değişiklikleri, yargı kararları ve açıklamalar için bkz Ayşe Köme Akpulat, Işs Mahkemelerinde Yargılamanın Özellikleri, (On İki Levha 2018) 142 ve 156.

81 Gülsevil Alpagut, 'Korumalı İşyeri Kavramı ve Korumalı İşyerleri Hakkında Yönetmeliğin Değerlendirilmesi’ (2006) (3) Sicil İş Hukuku Dergisi (Korumalı İşyeri) 29,31; John Kregel and David H. Dean, 'Sheltered vs Supported Employment: A Direct Comparison of Long-Term Earnings Outcomes for İndividuals with Cognitive Disabilities' (2001) <https:// worksupport.com/documents/shelteredchap3.pdf,> Erişim Tarihi 10.9.2019 63,64; Engin (n 64) 26.

82 Laurent Visier, 'Sheltered Employment For Persons With Disabilities' (1998) (137) International Labour Review 347,347; Uşan (n 33) 183; Alpagut, Korumalı İşyeri (n 81) 31.
} 
$\mathrm{Bu}$ işyerleri, özel veya kamu işverenlerince kurulabilmekte veya onlar tarafından desteklenebilmektedir. Korumalı işyerleri her şeyden önce, engellilere, rekabetten uzak, fiziki veya zihinsel yetersizliklerin dezavantaj yaratmadığı koruyucu bir çevrede istihdam olanağı sağlamakta; zaman içinde engellilerin mesleki becerilerinin gelişmesine ve çalışma hayatına geçişlerini kolaylaştırmaktadır ${ }^{83}$.

Hukukumuzda, Engelliler Hakkında Kanun'da korumalı işyeri, “Işs gücü piyasasına kazandırılmaları güç olan zihinsel veya ruhsal engellilere mesleki rehabilitasyon sağlamak ve istihdam oluşturmak amacıla Devlet tarafindan teknik ve mali yönden desteklenen ve çalışma ortamı özel olarak düzenlenen işyeri" olarak tanımlanmıştır (madde 3/1,i). Bu Kanun'un 14. maddesine dayanılarak, ilk olarak 2006 y1lında bir yönetmelik çıkartılmış ${ }^{84}$ daha sonra bu yönetmelik yerini, 2013 tarihli Korumalı İşyerleri Hakkında Yönetmelik' ${ }^{85}$ bırakmıştır. Yönetmeliğin korumalı işyeri tanımı da, Kanunda geçen "mesleki rehabilitasyon sağlamak" ifadesine yer vermemesi dışında, yukarıda yer verilen tanımla aynıdır. Her iki tanımda da, zihinsel veya ruhsal engellilere yer verilmiş, diğer engelli grupları sayılmamıştır. O halde kanun koyucu, korumalı işyerlerinde çalıştırılacak kimseleri zihinsel veya ruhsal engelliler olarak sınırlandırmıştır. Kanımca bu sınırlandırma isabetli değildir. Devletin korumalı işyerlerini mali kaynakları ölçüsünde desteklemesi beklendiğinden; bu işyerlerinde çalışmak üzere önceliğin, çalışma hayatına geçişte daha çok güçlük yaşayan zihinsel veya ruhsal engellilere verildiği düşünülebilir. Ancak yukarıda temel esaslarına yer verilen, devletin engelli istihdamına yönelik ödevleri karşısında, engelinin niteliğine bakılmadan bu imkânın tanınması kuşkusuz daha yerinde olacaktır. Üstelik önceki yönetmelikte, işyerine kabul bakımından "en az yüzde kırk oranında zihinsel, duygusal ve davranıssal engeli olmak veya diğer engel gruplarından ise \% 60 ve üzeri olmak" şartı aranmışken, yeni düzenlemede diğer engellilerin kapsam dışında tutulması doğru değildir.

Korumalı işyeri statüsünün kazanılması bakımından Yönetmelikte birtakım şartlar aranmıştır. Her şeyden önce işyerinin, Yönetmelikte belirlenen nitelikleri taşıyan en az sekiz engellinin çalıştığ 1 bir işyeri olması gerekir. Aynı zamanda, korumalı işyerlerinde çalışacak engelli bireylerin sayısının toplam işçi sayısına oranı yüzde yetmiş beşten az olmamalıdır. Bu kapsamda, işçi sayısının tespitinde, İş Kanunu madde 30'a benzer şekilde belirsiz ve belirli süreli iş sözleşmesine göre çalıştırılan işçiler esas alınır. Kısmi süreli iş sözleşmesine göre çalışanlar ise çalışma süreleri dikkate alınarak tam süreli çalışmaya dönüştürülür. (madde 4). Yönetmelikte, korumalı işyerinin taşıması gereken fiziksel şartlar ve donanıma da (emniyet, trafik güvenliği, yangından korunma gibi) ayrıca yer verilmiştir (madde 10-12). Aynı zamanda, bu işyerlerinde işyeri yöneticisi ve eğitici personel istihdamı da zorunlu tutulmuştur (madde 6). Bu

\footnotetext{
\$3 Çeşitli ülke uygulamaları hakkında bkz Visier (n 82) $348 \mathrm{ff}$.

${ }_{84}$ Yönetmelik hükümlerini değerlendiren Alpagut, Korumalı İşyeri (n 81$) 33$ ff; Recep Makas, 'Korumalı İşyeri' (2011) 25(6) Çimento İşveren 4,6 ff.

85 RG 26.11.2013/28833.
} 
şartları taşıyan işyerinin işvereni, korumalı işyeri statüsünün kazanılması için Aile ve Sosyal Politikalar İl Müdürlüğüne (bugün için Aile, Çalışma ve Sosyal Hizmetler İl Müdürlüğü) başvuruda bulunduktan sonra, talebin en geç otuz gün içinde değerlendirilmesi üzerine valilikçe, "Korumalı İşyeri Statüsü Belgesi” düzenlenir (madde 4 ve 7). Korumalı işyerinde istihdam edilebilmek için, en az yüzde kırk oranında zihinsel veya ruhsal engelli olmak, Kuruma kayıtlı olmak ve asgari çalışma yaşı olan on beş yaşını doldurmuş olmak gerekir. Bu şartları taşıyan engelli bireyler, Çalışma ve İş Kurumu İl Müdürlükleri aracıllı̆ı ile işyerlerine başvururlar. İşyeri, işe aldığ1 engelli bireyleri en geç bir ay içinde bildirmek zorundadır (madde 13, 14). Görüldüğ̈̈ gibi işe alma usulü bakımından, istihdamı kolaylaştırıcı bir biçimde, işverenin engelli işçileri çalıştırmak için Kuruma başvurması aranmamış, yalnızca işe aldığ 1 engellileri bildirmesi beklenmiştir.

Korumalı işyerlerine devlet tarafindan yapılan mali desteklerden biri, bu işyerlerinde çalışan engellilerin ücretlerinin belirli bir kısmının Hazine tarafından işverene ödenmesidir. $\mathrm{Bu}$ doğrultuda, İş Kanunu'na 2014 yılında 6518 sayılı Kanun'la Ek 1. madde eklenmiş ve korumalı işyerlerinde çalışan engellilere işverenlerince zamanında ödenmiş ücretlerinin a) Korumalı işyerlerinde çalışan her engelli için 2022 sayılı 65 Yaşını Doldurmuş Muhtaç, Güçsüz ve Kimsesiz Türk Vatandaşlarına Aylık Bağlanması Hakkında Kanun'un madde 2/1,a bendi gereğince ödenen aylık tutarı kadarı, b) 5084 sayılı Yatırımların ve İstihdamın Teşviki ile Bazı Kanunlarda Değiş̧iklik Yapılması Hakkında Kanun'un 2. maddesi kapsamındaki illerde kurulmuş bulunan korumalı işyerlerinde çalışan her engelli için ilaveten (a) bendi ile belirlenen tutarın yüzde yirmisi, c) Korumalı işyeri statüsü almak için ilgili mevzuatla çalıştırılması zorunlu olan sayıdan daha fazla engelli çalıştıran işyerlerinde, zorunlu sayının üstünde çalıştırılan her engelli için ilaveten (a) bendi ile belirlenen tutarın yüzde yirmisi, Hazine tarafından işverene ödenecektir. Ancak bunun için hem ücretlerin hem de ücretlere ilişkin yasal yükümlülüklerin zamanında ödenmesi gerekir. Ayrıca konu hakkında, Korumalı İşyerlerinde Çalışan Engellilerin Ücretlerine Karşılık İşverene Yapılacak Ödeme Hakkında Yönetmelik ${ }^{86}$ yürürlüktedir. Ayrıca, korumalı işyerlerinde çalıştırılan engelli sigortalıların, prime esas kazanç alt sınırı üzerinden hesaplanan sigorta primine ait işveren hisselerinin tamamı Hazine tarafından karşılanır. İşverenlerin çalıştırdıkları sigortalılarla ilgili olarak 5510 sayılı Kanun uyarınca aylık prim ve hizmet belgelerinin yasal süresi içerisinde Sosyal Güvenlik Kurumu'na verilmesi ve sigortalıların tamamına ait sigorta primlerinin sigortalı hissesine isabet eden tutarı ödemiş olması gerekir (İş Kanunu madde 30/6). Korumalı işyerlerine yönelik bu teşvikin, isabetli bir yaklaşım olduğu belirtilmelidir. Ancak bir işyerinin korumalı işyeri olarak değerlendirilmesi için çalıştırılması gereken asgari engelli işçi sayısının ve bu sayının diğer işçilere oranının yüksek olduğunu, bir başka ifadeyle bu şartı sağlamayı güçleştirdiğini söylemek mümkündür.

$86 \quad$ RG 30.4.2016/29699. 


\section{Sonuç}

Uluslararası düzenlemeler karşısında; Anayasamız ve iç hukukumuzda kabul edilen diğer esaslar dikkate alındığında, genel olarak engellilerin istihdamı konusunda önemli adımlar atıldığını söylemek mümkündür. Engellilerin istihdamından, engellilerin bir işyerinde çalışması değil aynı zamanda mesleki beceri kazandırılması, çalışmanın önündeki başta firsat eşitsizliği olmak üzere, soyut ve somut engellerin kaldırılması ve nitelikli istihdamın sürdürülebilirliği de anlaşılmalıdır. Bu anlamda ülkemizin hukuki düzenlemelerde kendisini gösteren engelli istihdamı politikasının, uluslararası sözleşmelerle büyük oranda uyum içinde olduğu görülmektedir. Ancak bir yaptırıma bağlanmış olsun ya da olmasın, hukuki düzenlemelerin bu konuda tek başına yeterli ve sorun çözücü olduğunu söylemek güçtür. Bu konuda, özellikle toplumdaki bilgi eksikliğinin ve kimi ön yargıların önüne geçmek son derece önemlidir.

Engellilerin çalışma hayatına katılması hedefine; engellilere iş alanları açmak, engelli işçi çalıştırmayı zorunlu kılmak, teşvik uygulamaları getirmek gibi tek başına istihdam politikaları ile varmak da mümkün değildir. Engelli bireylerin, eğitim ve sağlık kurumlarından, ulaşım araçlarından, sosyal ve kültürel hizmetlerden engelsiz biçimde yararlanmasının sağlanması, aynı zamanda engelli istihdamını da arttıracaktır. Yine engelliliğin çalışmaya ve üretmeye engel olmadığı, işi elde etmekten işyerine ulaşmaya ve iş koşullarına kadar uygun şartların sağlanması halinde her engelli bireyin çalışma hayatında yer alacağı konusunda toplumun bilgilendirilmesi de göz ardı edilmemeli ve bu konuda ciddi bir yaklaşım olarak değerlendirilmelidir.

İşverenlerin, belirli şartları taşıyan işyerlerinde engelli işçi çalıştırma yükümünde olması da, engelli istihdamına yönelik öteden beri kabul edilen bir yöntemdir. Hukukumuzda, bu yükümlülüğün dayanağı olan İş Kanunu'nun 30. maddesinde zaman içinde yapılan değişiklikler ve özellikle özel sektör işverenlerine yönelik teşviklerdeki artış, yerinde düzenlemeler olarak görünmektedir. Yine, işverenlerin çalıştıracakları işçileri kendi imkânlarıyla bulmalarına izin verilmesi de istihdamı kolaylaştıracak adımlardandır. Kuşkusuz, istihdamı sağlayıcı tedbirlerin, kota ve ceza yönteminden çok teşvik olarak düşünülmesi daha yapıcı bir yaklaşım olacaktır. Bu konuda, sorumluluğun işverenlere bırakılarak, "ne olursa olsun engelli çalıştırsın" anlayışının terk edilmesi gerekir. Zira engellinin bir işte çalışmasından çok uygun işte çalışması daha önemlidir. Türkiye'deki iş kollarının ve çalışma şartlarının ortaya konularak; engellilere uygun iş ve işyeri ortamının oluşturulması, çalışma yaşamının bu yönüyle de denetlenmesi, engellilerin niteliklerinin artırılması ve niteliklerinin farkına varmalarının sağlanması, bağımsız çalısmaya özendirilmesi gibi tedbirlerinin alınması sorumluluğu yalnızca işverenlere bırakmamak bakımından gereklidir.

Finansal Destek: Yazar bu çalışma için finansal destek almamıştır. 


\section{Bibliyografya/Bibliography}

Aile, Çalışma ve Sosyal Hizmetler Bakanlığı, Engelli ve Yaşlı İstatistik Bülteni (2019).

Alpagut G, ‘4857 Sayılı Yasa’da Özürlü, Eski Hükümlü ve Terör Mağduru Çalıştırma Yükümlülüğü’ (2004) (Nisan) Mercek Dergisi (Özürlü Çalıştırma) 118-129.

Alpagut G, ‘Özürlüler Hakkında Kanun ve Özürlü Çalıştırma Zorunluluğu Konusunda Mevzuattaki Son Değişiklikler' (2005) (Ekim) Mercek Dergisi (Son Değişiklikler) 152-160.

Alpagut G, 'Korumalı İşyeri Kavramı ve Korumalı İşyerleri Hakkında Yönetmeliğin Değerlendirilmesi' (2006) (3) Sicil İş Hukuku Dergisi (Korumalı İşyeri) 29-39.

Arıcı K, ‘Türk Hukukunda Sakat ve Eski Hükümlü Çalıştırma Zorunluluğu ve Uygulaması' (1982) 73(1) Adalet Dergisi 84-97.

Beveridge WH, Full Employment in A Free Society (2nd edition, 1960)

Bozkurt T, 'Anayasa Mahkemesi'nin 4857 Sayılı İş Kanunu'ndaki Engelli ve Eski Hükümlü Çalıştırma Zorunluluğunun Anayasa'ya Uygun Olduğuna Dair Verdiği Karar Üzerine Düşünceler' (2009) (2) Ankara Barosu Dergisi 98-105.

Caniklioğlu N, Hastalık ve Sakatlı̆̆ın Hizmet Akdine Etkisi (Beta 2002).

Centel T, ‘Özürlü Çalıştırma Yükümüne Aykırılığa İlişkin Cezai Sorumluluk Esasları' (2010) (20) Sicil İş Hukuku Dergisi 5-10.

Çelik N, Caniklioğlu N and Canbolat T, İş Hukuku Dersleri, (31st edition, Beta 2018).

Ekmekçi Ö, 'Yeni Tüzük Hükümleri Uyarınca Sakat İşçi Çalıştırma Yükümü’ (1987) $(4,5,6)$ İstanbul Barosu Dergisi (Sakat İşçi Çalıştırma) 309-327.

Ekmekçi Ö, 'Özürlü, Eski Hükümlü ve Terör Mağduru İstihdamında Yaşanan Sorunlar ve İtiraz Usulündeki Değişiklikler' (2005) 19(5) Çimento İşveren Dergisi (Yaşanan Sorunlar) 42-53.

Engin EM, ‘Çalışma Yaşamında Özürlülük' (2009) (2) Galatasaray Üniversitesi Hukuk Fakültesi Dergisi 13-30.

Güzel A, Okur AR and Caniklioğlu N, Sosyal Güvenlik Hukuku, (17th edition, Beta 2018).

Kregel J and Dean HD, 'Sheltered vs Supported Employment: A Direct Comparison of Long-Term Earnings Outcomes for İndividuals with Cognitive Disabilities', (2001) <https://worksupport. com/documents/shelteredchap3.pdf,> 63-83, Erişim Tarihi 10.9.2019.

Köme Akpulat A, İş Mahkemelerinde Yargılamanın Özellikleri, (On İki Levha 2018).

Makas R, 'Korumalı İşyeri' (2011) 25(6) Çimento İşveren Dergisi 4-13.

Manav AE, 'İşverenin Özürlü, Eski Hükümlü ve Terör Mağduru Çalıştırma Zorunluluğu' (2006) 10(1-2) Gazi Üniversitesi Hukuk Fakültesi Dergisi 137-169.

Savaş FB, 'Çalışma Yaşamında Engelli Bireyin İstihdam Sorunları ve Yasal Yükümlülükler' (2014) 2 Prof. Dr. Feridun Yenisey’e Armağan (Beta 2014) 2615-2646.

Stoevska V, 'Disability Statistics - Labour Market Characteristics of Persons with Disabilities' (2018) 20th International Conference of Labour Statisticians 10 - 19 October 2018, Geneva (ILO 2018).

Subaşı İ, 'İş Hukukunda Özürlülerin Durumu' (2011) Prof. Dr. Tankut Centel'e Armağan (İstanbul Üniversitesi Yayını 2011) 477-540.

Süzek S, Işs Hukuku (18th edition, Beta 2019).

Şen M, 'İnsan Hakları Bağlamında Çalışma Hakkı' (2013) 2(2) Marmara Üniversitesi Hukuk Fakültesi Dergisi 13-37.

Şen M, 'Türkiye'de Engellilere Yönelik İstihdam Politikaları' (2018) 8(2) Sosyal Güvenlik Dergisi 129-152. 
Talas C, 'Çalışma Hakk1 ve Türkiye'deki Durum' (1991) XLVI(1) Ankara Üniversitesi Siyasal Bilgiler Fakültesi Dergisi 407-421.

Tuncay AC and Ekmekçi Ö, Sosyal Güvenlik Hukuku Dersleri, (19th edition, Beta 2017).

Tunçomağ K, 'Sakat ve Eski Hükümlü Çalıştırma Yükümü’ (1974) 40(4) İstanbul Üniversitesi Hukuk Fakültesi Mecmuası 375-391.

Uşan MF, İş Hukukunda Sakat İstihdamı, (Türkiye Sağlık İşçileri Sendikası 1999).

Ünal C, Özürlülerin Sosyal Güvenlik Haklarl, (Beta 2012).

Visier L, 'Sheltered Employment For Persons With Disabilities' (1998) (137) International Labour Review 347-365.

WHO, World Report on Disability (2011).

WHO, International Classification of Impairments, Disabilities and Handicaps (1976).

Yıldız GB, 'Türk İş Hukukunda Özürlülük ve Sağlı Durumuna Dayalı Ayrımcılık Yasağı' (2008) (10) Sicil İş Hukuku Dergisi 80-87.

\section{Elektronik Kaynaklar/Electronic Resources}

http://www.tuik.gov.tr

https://ec.europa.eu

https://www.ilo.org.

https://www.iskur.gov.tr

https://www.kazanci.com

https://www.ohchr.org

https://www.un.org 
